\title{
Pollen morphology of Lathyrus (Leguminosae) taxa belonging to Lathyrus, Orobastrum and Cicercula sections from Turkey
}

\author{
Fatma Güneş
}

Received: 13 March 2012/ Accepted: 24 June 2012

(C) The Author(s) 2012. This article is published with open access at Springerlink.com

\begin{abstract}
The pollen morphology of 20 wild taxa belonging to Lathyrus (Syn: Eulathyrus), Orobastrum (Taub.) Boiss. and Cicercula (Medic.) Gren. \& Godr. sections of Lathyrus L. grown in Turkey (L. rotundifolius Wild. subsp. miniatus (Bieb. ex Steven) P.H. Davis, L. grandiflorus Sibth. \& Sm., L. saxatilis (Vent.) Vis., L. vinealis Boiss. \& Noë, L. inconspicuus L. var. inconspicuus, L. inconspicuus var. stenophyllus (Boiss.) Rech. f., L. tauricola P.H. Davis, L. woronowii Bornm., L. hierosolymitanus Boiss., L. cassius Boiss., L. gorgoni Parl. var. gorgoni, L. pseudo-cicera Pamp., L. sativus L., L. blepharicarpus Boiss., L. stenophyllus Boiss. \& Heldr., L. belinensis Maxted \& Goyder, L. phaselitanus Hub.-Mor. \& P.H.Davis, L. chrysanthus Boiss., L. chloranthus Boiss., and L. trachycarpus (Boiss.) Boiss were examined by light microscopy (LM) and scanning electron microscopy (SEM) in this study. The pollen grains were 3-zonocolporate, spheroidal, subprolate, and prolate $(P / E=0.99-1.48)$ types, and were medium in size (equatorial view: rectangular or elliptical-obtuse-convex; polar view: circular, triangular and quinquangular-obtuse-convex). The smallest pollen grains belonged to $L$. tauricola $(P=30.94 /$ $E=31.20)$ and the largest to $L$. grandiflorus $(P=50.60 /$ $E=36.40$ ). The ornamentation was reticulate and reticulate-granulate in the mesocolpium, and usually psilate in the apocolpium. Some photographs included in this work were taken using both LM and SEM.
\end{abstract}

Keywords Cicercula Lathyrus - Orobastrum . Pollen morphology · Turkey

F. Güneş $(\bowtie)$

Department of Pharmaceutical Botany, Faculty of Pharmacy,

Trakya University, Edirne, Turkey

e-mail: drgunes@gmail.com

\section{Introduction}

Lathyrus L. is the largest genus in the tribe Fabaceae of the family Fabaceae, with about 200 known species worldwide. The eastern Mediterranean region is the main centre of diversity for the genus, which is less diversified in North and South America (Bässler 1980; Kupicha 1983; Simola 1986). In Turkey, 66 species and 76 taxa of Lathyrus have been identified (Davis 1970, 1988; Güneş and Özhatay 2000). The endurance of Lathyrus against drought (e.g., L. sativus, L. ochrus) is well known, and the economic value of this is high. L. sylvestris is utilised to prevent erosion in the disrupted and burned-down fields of America (Whyte et al. 1953; Yamamoto and Fujwwara 1984). The roots of $L$. tuberosus are consumed as food in the East Anatolian region of Turkey, L. ochrus and L. sativus are used for agricultural processes in Turkey (Güneş 2006), and approximately 33 species are used for ornamental purposes (Campbell 1997).

In Turkey, the following characteristics are seen in Lathyrus species: perennial, procumbent to climbing; angled or winged stems; leaves are tendrillous, with leaflets that are one-paired, and either broadly elliptical or linear, with parallel veins and semi-sagittate stipules; racemes are comprised of three or many flowers, with a twisted style; legumens are glabrous, with the upper suture not being two winged. Orobastrum characteristics are annual; procumbent to climbing; angled or sometimes have very narrowly winged stems; tendrillous or aristate leaves; leaflets are one-paired or several-paired, linear to elliptic, with parallel veins; peduncles are one-flowered; and legumens are glabrous or pubescent, with the upper suture not being 2-winged. Cicercula is the largest and most difficult section of Lathyrus in Turkey. In this section the flower colour is very important for identification, and often changes 
drastically on drying (brick-red flowers turn a bluish-purple), making field notes on flower colour essential. This group is very diverse and problematic in Turkey (Davis 1970). Section Cicercula contains approximately 25 annual species throughout middle and southern Europe, southwest Asia and north Africa (Post 1932; Fedchenko 1948; Ball 1968; Davis 1970, 1988; Dakijordanov 1976; Meikle 1977; Townsend and Guest 1977; Rechinger 1979; Tutin and Heywood 1981; Zohary 1987; Güneş and Özhatay 2000). The species in this group have very well-framed characteristics: an annual procumbenec to climbing; stems that are winged in the upper part; leaves are tendrillous or rarely aristate; leaflets are one-paired, elliptic to linear, with parallel to pinnate-parallel veins, and stipules are semisagittate; peduncles have one to several flowers with a style that is usually twisted; the colour of the flowers varies (bright red, brick red, soft yellow, orange, gingery orange, pink, lilac or light purple, sky blue, rose or clear pink with purplish, bluish purple, golden, bright yellow or sulphur, wine red); and legumens are glabrous or hairy, with the upper suture being two-winged or wingless (Davis 1970).

The pollen morphology of some taxa belonging to the Lathyrus species has been studied by various researchers, especially in Turkey, but also throughout the world. The pollen morphology of the taxa in Turkey has been determined for L. digitatus Aytug et al. (1971), L. undulatus, L. sylvestris and L. ochrus (Günes and Cirpici 1998), L. pratensis, L. layardii, L. laxiflorus subsp. laxiflorus, L. laxiflorus subsp. angustifolius and L. czeczottianus (Günes and Aytug 2010), L. annuus, L. cicera, L. gorgoni var. pilosus and L. hirsutus (Günes and Cirpici 2010), L. niger, L. palustris subsp. palustris, L. tuberosus, L. sphaericus, L. setifolius, L. clymenum, L. nissolia, L. aphaca var. aphaca, L. aphaca var. affinis and L. aphaca var. biflorus (Günes 2011b), and L. pallescens, L. brachypterus, L. haussknechtii, L. karsianus, L. satdaghensis, $L$. nivalis, $L$. atropatanus, $L$. armenus, $L$. cyaneus var. cyaneus, L. cyaneus var. pinnatus, L. digitatus, L. tukhtensis, L. variabilis, L. spatulatus, L. elongatus, L. cilicicus and L. boissieri (Günes 2011a). Apart from in Turkey, the morphological features of pollen have been determined for L. niger (Gapotchka and Chamara 1972; Gapotchka 1974), L. palustris (Faegri and Iversen 1989) in Russia; L. sylvestris, $L$. pratensis, L. maritimus, $L$. nissolia and L. montanus (Moore et al. 1991) in France; L. emodii, L. cicera, L. humulis and L. pratensis (Perveen and Qaiser 1998) in Pakistan; L. grandiflorus, L. latifolius, L. sylvestris, L. tuberosus (Tosheva et al. 2004), L. alpestris, L. aureus, L. linifolius, L. niger, L. palustris, L. transsilvanicus, L. venetus and L. vernus (Tosheva and Tonkov 2005), and $L$. digitatus, L. filiformis, L. pallescens, L. pancicii and L. pannonicus (Tosheva and Tonkov 2007) in Bulgaria.
The Lathyrus group in Turkey involves five taxa in total, with one taxon that is endemic (L. undulatus). Section Orobastrum contains eight taxa, two of which are endemic (L. tauricola and L. woronowii), and the Cicercula section contains 18 taxa, with four endemic taxa (L. lycicus Boiss., L. belinensis, L. phaselitanus, L. trachycarpus). The pollen of some taxa belonging to Lathyrus, Orobastrum and Cicercula sections have been analysed: L. tuberosus, $L$. undulatus, $L$. sylvestris, $L$. sphaericus, $L$. setifolius, $L$. annuus L. cicera, L. gorgoni var. pilosus and L. hirsutus (by Günes and Cirpici 1998, 2010; Günes 2011b). These researchers have provided information about the pollen type (3-zonocolporate), pollen shape (spheroidal, subprolate, prolate), structure (tectate infrastructure) and ornamentation (reticulate-granulate) of the taxa belonging to the Cicercula section. Furthermore, Moore et al. (1991), Güneş and Aytug (2010) and Günes (2011a, b) also noted that the endexine thickens two to three times around the colpus and the porus, and forms a large costae formation.

Therefore, the aim of this study is to determine the pollen morphological properties of 20 Lathyrus taxa belonging to Lathyrus, Orobastrum and Cicercula sections. The secondary aim is to use these properties in the identification of species. In this study, the morphological features of the pollen of 17 taxa, with the exception of L. inconspicuus var. inconspicuous, L. saxatilis and L. chloranthus (Kahraman et al. 2012), distributed throughout Turkey, were examined for the first time.

\section{Materials and methods}

Twenty taxa of Lathyrus were collected from their natural habitats in Turkey between 2004 and 2011 (Table 1). Two taxa (L. marmoratus Boiss. \& Bl. and L. lycicus) were not collectable from their natural habitats, and there was no record of any examples in any of the herbariums examined. All of the collected specimens were identified and deposited in the Herbarium of Kafkas University, Faculty of Arts and Sciences, in the Department of Biology. The pollen was analysed in preparations made using the non-acetolysis method (Wodehouse 1959) under a light microscope. Except for the taxa L. grandiflorus, L. sativus, L. belinensis and $L$. phaselitanus, for each taxon the pollen belonging to the flowers collected from at least two localities was used. Ten characteristics of the pollen were examined under a magnification of $1,000 \times$ : polar diameter $(P)$, equatorial diameter $(E)$ [measured by 400 times magnitude], colpus width (clt; colpus width was measured in regions close to the porus), porus length (plg), porus width (plt), one edge of the polar triangle $(t)$, exine thickness, intine thickness and costae. The structural (exine) and sculptural (exine ornamentation) forms were also shown (Table 2). The 
Table 1 The specimens examined and their distribution throughout the world

\begin{tabular}{|c|c|c|c|}
\hline Sections & Taxa & Distribution in the world & Locality \\
\hline Lathyrus & L. rotundifolius subsp. miniatus & Caucasia, N. Iraq, N. Iran & $\begin{array}{l}\text { A8 Bayburt: Bayburt-Gümüşhane road, Akşar village, } \\
\text { field side, 1,614 m, 15.07.2009, F. Güneş } 2466 \text {. A9 } \\
\text { Kars: Kars-Susuz road, } 8 \mathrm{~km} \text {, field side, } 1,780 \mathrm{~m} \text {, } \\
\text { 19.06.2004, F.Güneş 16. B9 Bitlis: Mountain Kirkor, } \\
\text { 1,853 m, 15.06.2008, F. Güneş } 1851\end{array}$ \\
\hline
\end{tabular}

\section{L. grandiflorus}

Orobastrum L. saxatilis

L. vinealis

L. inconspicuus var. inconspicuus

L. inconspicuus var. stenophyllus

L. tauricola (end)

L. woronovii (end)

L. hierosolymitanus

Cicercula Cicercula

L. hierosolymitanus
L. cassius
L. gorgoni var. gorgoni
L. pseudo-cicera
L. blepharicarpus

L. blepharicarpus

L. stenophyllus
Greece, S. Balkans, Macedonia, S. Italy, Sicily and W. Anatolia

S. Europe, Crimea, Cyprus, Syrian Desert, Cyrenaica

N. Iraq, W. Iran. E. Anatolia

S. Europe, SW and C. Asia

Syria, NW and C. Iran, E. Afghanistan. SE Anatolia

S. Anatolia (Isparta)

NE. Anatolia (Çoruh valley)

S. Anatolia, W. Syria,
N. Egypt, Cyrenaica
E. Medit. element

S. and SE Anatolia, W. Syria, Cyprus, N. Iraq

E. Medit. element

S. and SE Anatolia, Sicily, Sardinia, Cyrenaica, N. Sinai, W. Syria, Cyprus, N. Iraq. E. Medit. element

SE Anatolia, Cyrenaica, N. Egypt, Palestine, Syrian Desert, N. Iraq, W. Iran. Ir.-Tur. element

Widespread except in the NE, S. and C. Europe, N. Africa, SW Asia

S. Anatolia, W. Syria, Cyprus. E. Medit. element

S. Anatolia, Islands, Crete \& W. Syria, E. Medit. element
A1(A) Balıkesir: Erdek, Ocaklar village, $65 \mathrm{~m}$, 13.06.2011, F. Güneş 2749

C3 Isparta: Aksu, around Zindan Cave, 18.06.2011, F. Güneş 2761. Kovada Lake area, 18.06.2011, F. Güneş 2769

B9 Bitlis: Bitlis-Baykan road, $10 \mathrm{~km}$, roadside, 1,419 m, 09.05.2009, F. Güneş 2105. C7: Urfa: Diyarbakır-Urfa road, border of Urfa, 1,105 m, 11.05.2009, F. Güneş 2142

A9 Kars: Subatan village, cultivated fields, 1,620 m, 06.06.2006, F. Güneş 140. B9 Bitlis: Bitlis-Baykan road, $10 \mathrm{~km}$, roadside, $1419 \mathrm{~m}, 09.05 .2009, F$. Güneş 2106. C7 Urfa: Siverek-Bucak road, Kalınağaç village, fields, 780 m, 12.05.2009, F. Güneş 2176

C7 Urfa: Siverek-Bucak road, Kalınağaç village, fields, 780 m, 12.05.2009, F. Güneş 2177

C3 Isparta: Aksu, around Zindan Cave, 1,209 m, 12.06.2009,

F. Güneş 2344. Kovada Lake area, 1,058 m, 18.06.2011,

F. Günes 2768

A9 Artvin: Çoruh valley, Yusufeli road, $511 \mathrm{~m}$, 19.05.2009, F. Güneş 2190. Yusufeli-Sukavuşumu, 430 m, 23.05.2009, F. Güneş 2206

C6: Osmaniye: Osmaniye-Toprakkale road $8 \mathrm{~km}$, cultivated and uncultivated fields, $50 \mathrm{~m}, 18.04 .2009$, F. Güneş 2006. Hatay: Hatay-Kışlak road $2 \mathrm{~km}$ to the parting way of Kışlak, $160 \mathrm{~m}, 05.07 .2011, F$. Günes 2776

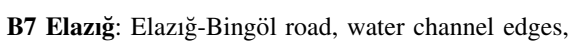
860 m, 11.07.2008, F. Güneş 1972.C5 Mersin: Silifke-Taşucu road $4 \mathrm{~km}$, İmamuşağı village, 21.04.2009, F. Güneş 2038. C8 Diyarbakır: Ovabă̆ Zelyağdı village, roadside, $735 \mathrm{~m}, 11.05 .2009, F$. Güneş 2135

C6 Hatay: Yayladağ, roadside and uncultivated fieids, 393 m, 19.04.2009, F. Güneş 2022. C8 Diyarbakır: Ovabağ Özyar village, road and field sides, $735 \mathrm{~m}$, 11.05.2009, F. Güneş 2132

C7 Urfa: Siverek-Urfa road, Karakoyun village, roadside, 12.05.2009, F. Güneş 2184. C8 Diyarbakır: Ovabağ Zelyağdı village, roadside, 735 m, 11.05.2009, F. Güneş 2137

B8 Muş: Malazgirt, cultivated fields, $1,511 \mathrm{~m}$, 15.06.2008,

F. Güneş 1852

C5 Mersin: Mersin-Silifke road $45 \mathrm{~km}$, oak scrubs, 20.04.2009,

F. Güneş 2035. C6 Hatay: Belen-Hatay road 5 km, forest side and roadside, $565 \mathrm{~m}, 18.04 .2009$, F. Güneş 2008

C3 Antalya: Faselis National Park, 23.04.2009, s.1., F. Güneş 2066. C4 Mersin: Taşucu-Aydıncık road, Akdere village, under and open forest, $53 \mathrm{~m}$, 21.04.2009, F. Güneş 2041 
Table 1 continued

\begin{tabular}{|c|c|c|c|}
\hline Sections & Taxa & Distribution in the world & Locality \\
\hline & L. belinensis (end) & S. Anatolia (Antalya) & $\begin{array}{l}\text { C3 Antalya: Kemer-Kumluca road } 45 \mathrm{~km} \text {, } \\
\text { roadside and open forest, } 375 \mathrm{~m}, 23.04 .2009 \text {, } \\
\text { F. Güneş } 2071\end{array}$ \\
\hline & L. phaselitanus (end) & S. Anatolia (Antalya) & $\begin{array}{l}\text { C3 Antalya: Faselis National Park, s.l., } \\
\text { 23.04.2009, F. Güneş } 2068\end{array}$ \\
\hline & L. chrysanthus & $\begin{array}{l}\text { SE Anatolia, Lebanon, Syrian Desert. Ir.-Tur. } \\
\text { element }\end{array}$ & $\begin{array}{l}\text { C7 Urfa: Siverek-Bucak road, Kalınağaç } \\
\text { village, border of cultivated and uncultivated } \\
\text { fields, } 780 \mathrm{~m}, 12.05 .2009, F \text {. Güneş } 2175 \text {. C8 } \\
\text { Diyarbakir: Mountain Karacadağ, field side } \\
\text { and volcanic rockys, } 1,100 \mathrm{~m}, 11.05 .2009 \text {, } \\
\text { F. Güneş } 2155\end{array}$ \\
\hline & L. chloranthus & $\begin{array}{l}\text { Inner and E. Anatolia, N. Iraq, Iran, Armenia. } \\
\text { Ir.-Tur. element }\end{array}$ & $\begin{array}{l}\text { A8 Bayburt: Bayburt-Gümüşhane road, Akşar } \\
\text { village, field side, 1,614 m, 15.07.2009, } \\
\text { F. Güneş } 2465 . \text { B9 Ağrı: Hamur-Tutak road } \\
\text { 8 km, riverside, 1,624 m, 07.07.2009, } \\
\text { F. Güneş } 2444\end{array}$ \\
\hline & L. trachycarpus (end) & SE Anatolia (Karacadağ) & $\begin{array}{l}\text { C7 Urfa: Siverek-Bucak road, Kalınağaç } \\
\text { village, border of cultivated and uncultivated } \\
\text { fields, } 780 \mathrm{~m}, 12.05 .2009, F \text {. Güneş } 2180\end{array}$ \\
\hline
\end{tabular}

City names and their grids are given in bold

arithmetic means, standard deviations and variations were calculated for each characteristic. The standard deviations for the characteristics that had no requirement for multiple measurements are not given. For SEM, the pollen grains were mounted onto stubs with double-sided adhesive tape and were then coated with gold. These coated pollen grains were then examined. The microphotographs were obtained using LEO 440 SEM at a magnification of 2,000-13,000× and $\mathrm{LM}$ at $1,000 \times$. The morphological descriptions of the pollen follow the terminology of Moore et al. (1991) and Punt et al. (1994).

\section{Results}

General remarks

The morphological characteristics of the pollen of 20 taxa belonging to sections Lathyrus, Orobastrum, and Cicercula, indicating a natural dispersion in Turkey, were studied. The characteristics were measured in preparations made using a non-acetolysis method, and their numerical values are given in Table 2. The pollen shape was found to be: spheroidal in $L$. inconspicuus var. inconspicuus, L. inconspicuus var. stenophyllus, L. tauricola, and L. hierosolymitanus; subprolate in $L$. rotundifolius subsp. miniatus, L. saxatilis, L. vinealis, L. gorgoni var. gorgoni, L. pseudo-cicera, L. sativus, L. blepharicarpus, L. stenophyllus, L. belinensis, L. chrysanthus, and L. chloranthus; subprolate to prolate in L. trachycarpus; and prolate in
L. grandiflorus, L. woronowii, and L. cassius. Descriptions of the pollen of these taxa are provided below:

L. rotundifolius subsp. miniatus (Table 2; Figs. 1a, b, 2a-c)

Pollen type: 3-zonocolporate.

Pollen shape: subprolate $P / E: 1.21$

Dimensions: medium size $(P \times E=41.29 \times 34.11 \mu \mathrm{m})$.

Apertures: apertures with an intine protrusion (thickening of the middle of the aperture membrane); ectoapertures-colpi: long, straight, nearly reaching the poles, narrow, deep, with acute ends, borders distinct, broader on pori, clg: $33.11 \mu \mathrm{m}$, clt: $2.12 \mu \mathrm{m}$; endoapertures-pori: large, borders distinct, lalongate, with an annulus (thickness sexine) and costae (thickness nexine), plg: $8.59 \mu \mathrm{m}$, plt: $11.68 \mu \mathrm{m}$ and plg/plt: 0.74 .

Outlines: equatorial view rectangular-obtuse-convex; polar view circular to triangular-obtuse-convex.

Ornamentation: reticulate-slightly granulate, reticules big, different in size and shape in the mesocolpium, decreasing towards the apocolpium and colpus. The polar area and colpus area are psilate.

Ex/int: $\cong 1 / 2$

Exine: $\cong 1.14 \mu \mathrm{m}$.

L. grandiflorus (Table 2; Figs. 1c, d, 2d-f)

Pollen type: 3-zonocolporate.

Pollen shape: prolate $P / E: 1.39$

Dimensions: medium size $(P \times E=50.60 \times 36.40 \mu \mathrm{m})$.

Apertures: apertures with an intine protrusion (thickening of the middle of the aperture membrane); ectoapertures-colpi: long, straight, wide, deep, with acute ends, the borders very distinct, broader on pori, clg: $36.48 \mu \mathrm{m}$, clt: 


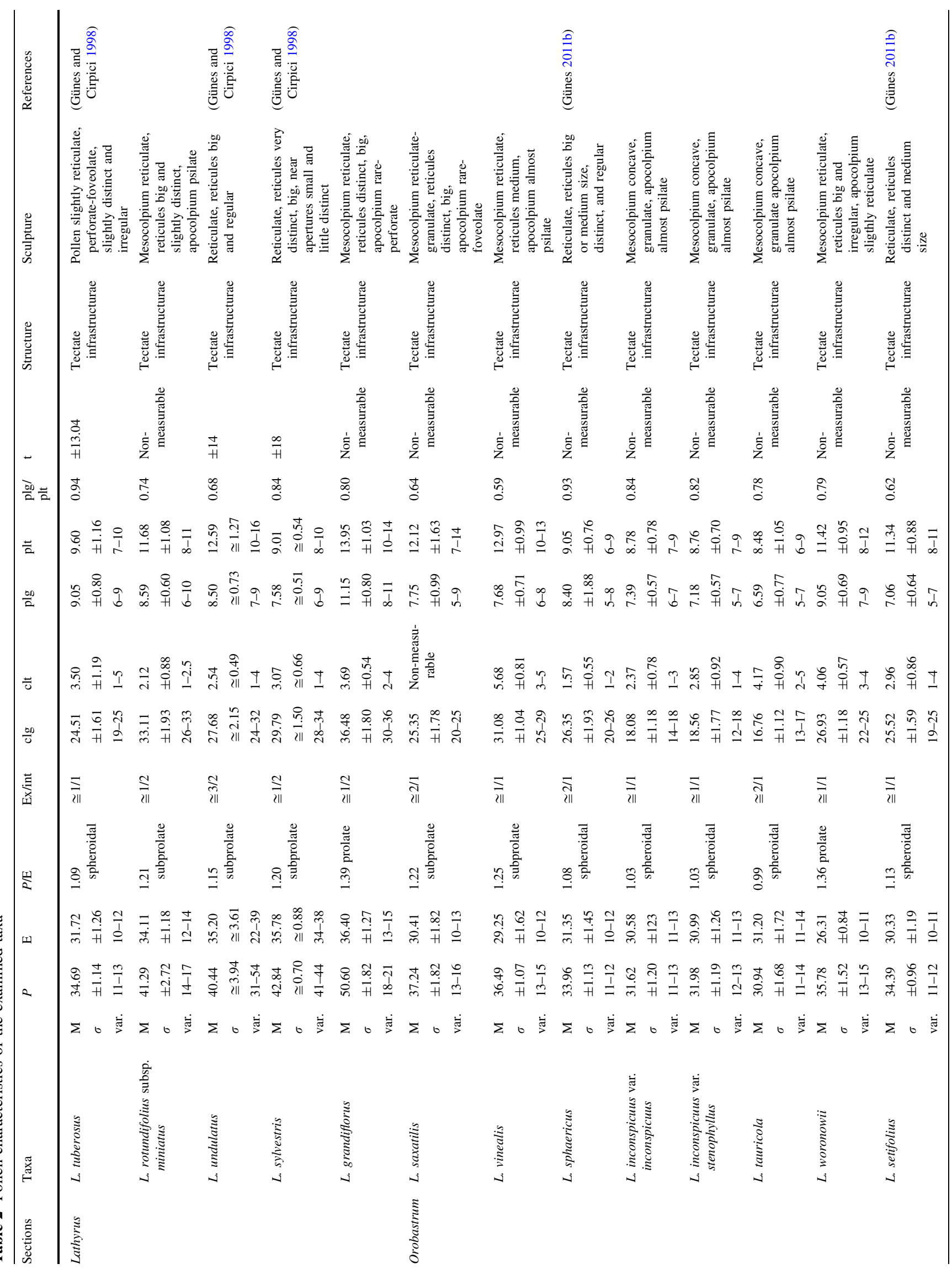




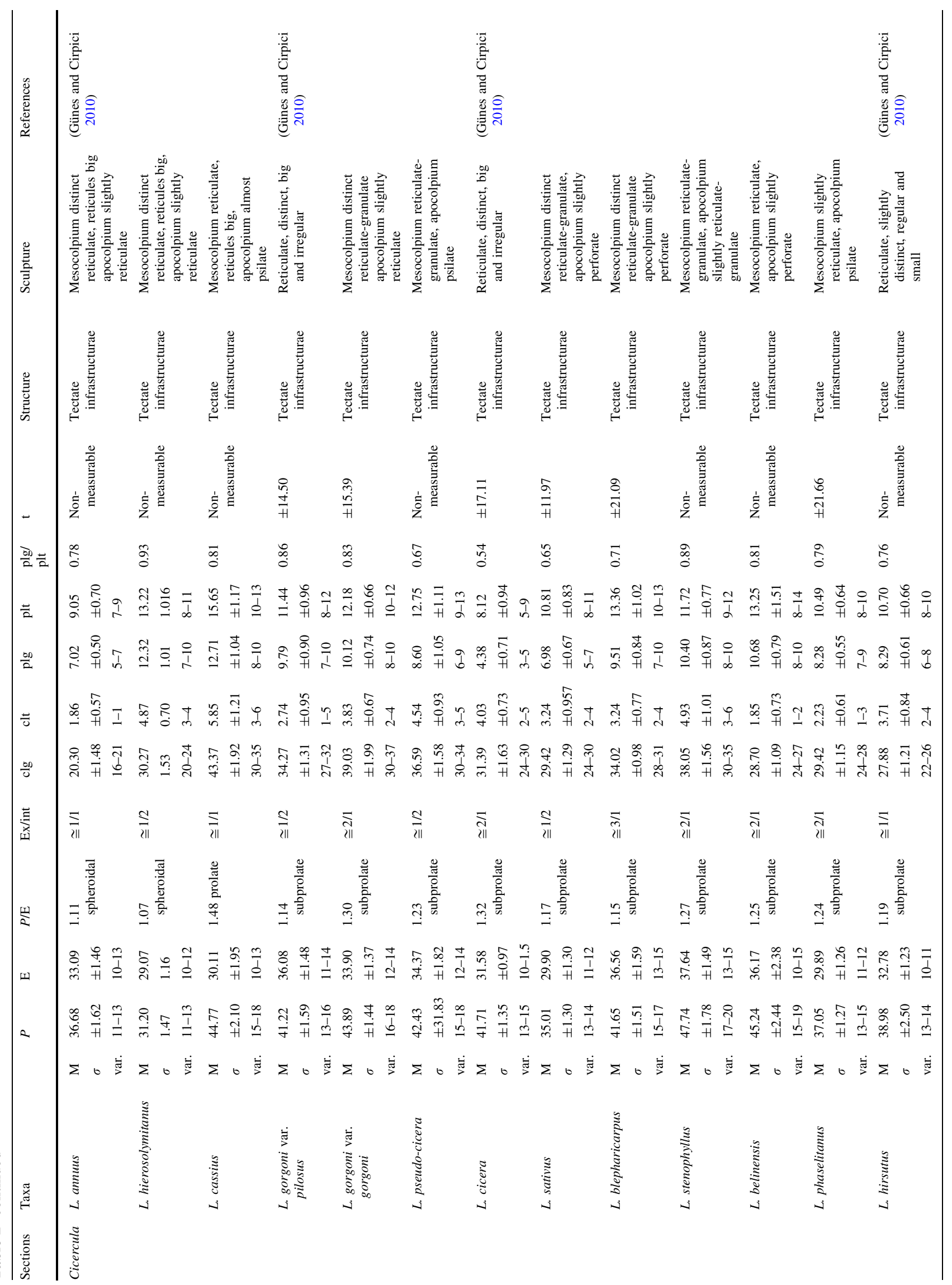




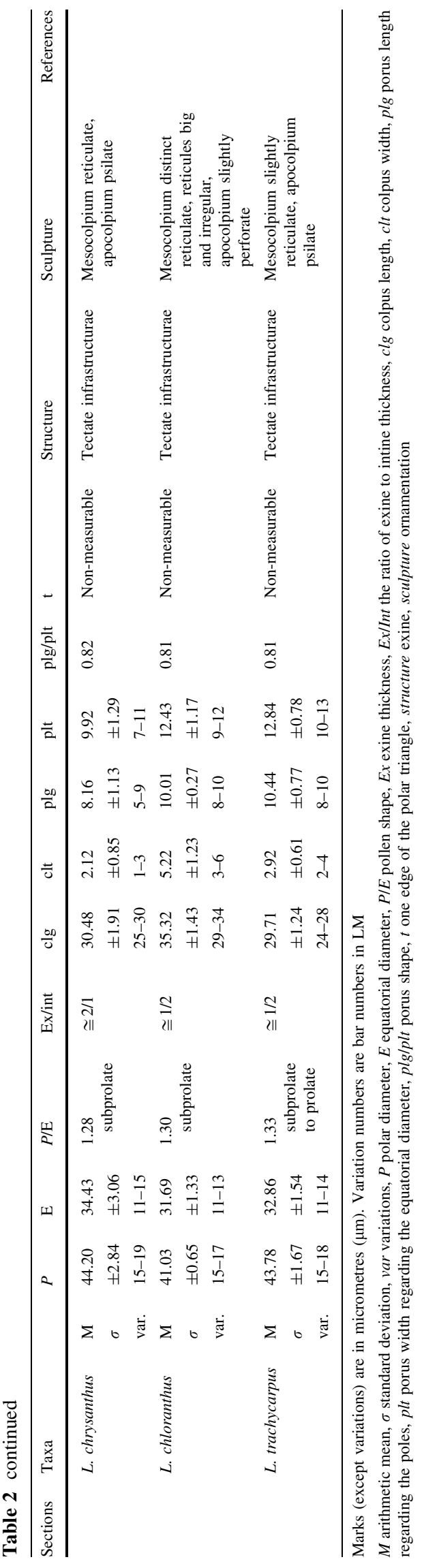

$3.69 \mu \mathrm{m}$; endoapertures-pori: large, borders distinct, protruding, lalongate, with an annulus (thickness sexine) and costae (thickness nexine) non-measurable, plg: $11.15 \mu \mathrm{m}$, plt: $13.95 \mu \mathrm{m}$ and plg/plt: 0.80 .

Outlines: equatorial view rectangular-obtuse-convex; polar view circular to triangular-obtuse-convex.

Ornamentation: reticulate, reticules big, different in size and shape, decreasing towards the apocolpium and colpus area psilate. The apocolpium is perforate.

Ex/int: $\cong 1 / 2$.

Exine: $\cong 1.14 \mu \mathrm{m}$.

L. saxatilis (Table 2; Figs. 1e, f, 2g-i)

Pollen type: 3-zonocolporate.

Pollen shape: subprolate $P / E$ : 1.22 .

Dimensions: medium size $(P \times E=37.24 \times 30.41 \mu \mathrm{m})$.

Apertures: apertures with an intine protrusion (thickening of the middle of the aperture membrane); ectoapertures-colpi: not long, borders not distinct, clg: $25.35 \mu \mathrm{m}$, clt: non-measurable, colpus and porus area granulate; endoapertures-pori: large, borders distinct, protruding, lalongate, with an annulus (thickness sexine) and costae (thickness nexine) non-measurable, plg: $7.75 \mu \mathrm{m}$, plt: $12.12 \mu \mathrm{m}$ and plg/plt: 0.64 .

Outlines: equatorial view elliptical-obtuse-convex; polar view circular to triangular.

Ornamentation: distinct reticulate-granulate, reticules different in size and shape, decreasing towards the apocolpium. The colpus area and porus area granulate, the apocolpium are almost psilate to perforate.

Ex/int: $\cong 2 / 1$.

Exine: $\cong 2.28 \mu \mathrm{m}$.

L. vinealis (Table 2; Figs. 1g, h, 2k-m)

Pollen type: 3-zonocolporate.

Pollen shape: subprolate $P / E$ : 1.25 .

Dimensions: medium size $(P \times E=36.49 \times 29.25 \mu \mathrm{m})$.

Apertures: apertures with an intine protrusion (thickening of the middle of the aperture membrane); ectoapertures-colpi: long, straight, nearly reaching the poles, wide, deep, with acute and obtuse ends, the borders little distinct, clg: $31.08 \mu \mathrm{m}$, clt: $5.68 \mu \mathrm{m}$; endoapertures-pori: large, borders distinct, lalongate, with an annulus (thickness sexine) and costae (thickness nexine) $2.28 \mu \mathrm{m}$, plg: $7.68 \mu \mathrm{m}$, plt: $12.97 \mu \mathrm{m}$ and plg/plt: 0.59 .

Outlines: equatorial view rectangular-obtuse-convex; polar view circular to triangular.

Ornamentation: reticulate, reticules big and distinct, different in size and shape, decreasing towards the apocolpium. The colpus-porus area and apocolpium are psilate.

Ex/int: $1 / 1$.

Exine: $\cong 1.14 \mu \mathrm{m}$.

L. inconspicuus var. inconspicuus (Table 2; Figs. 3a, b, $4 a-c)$ 


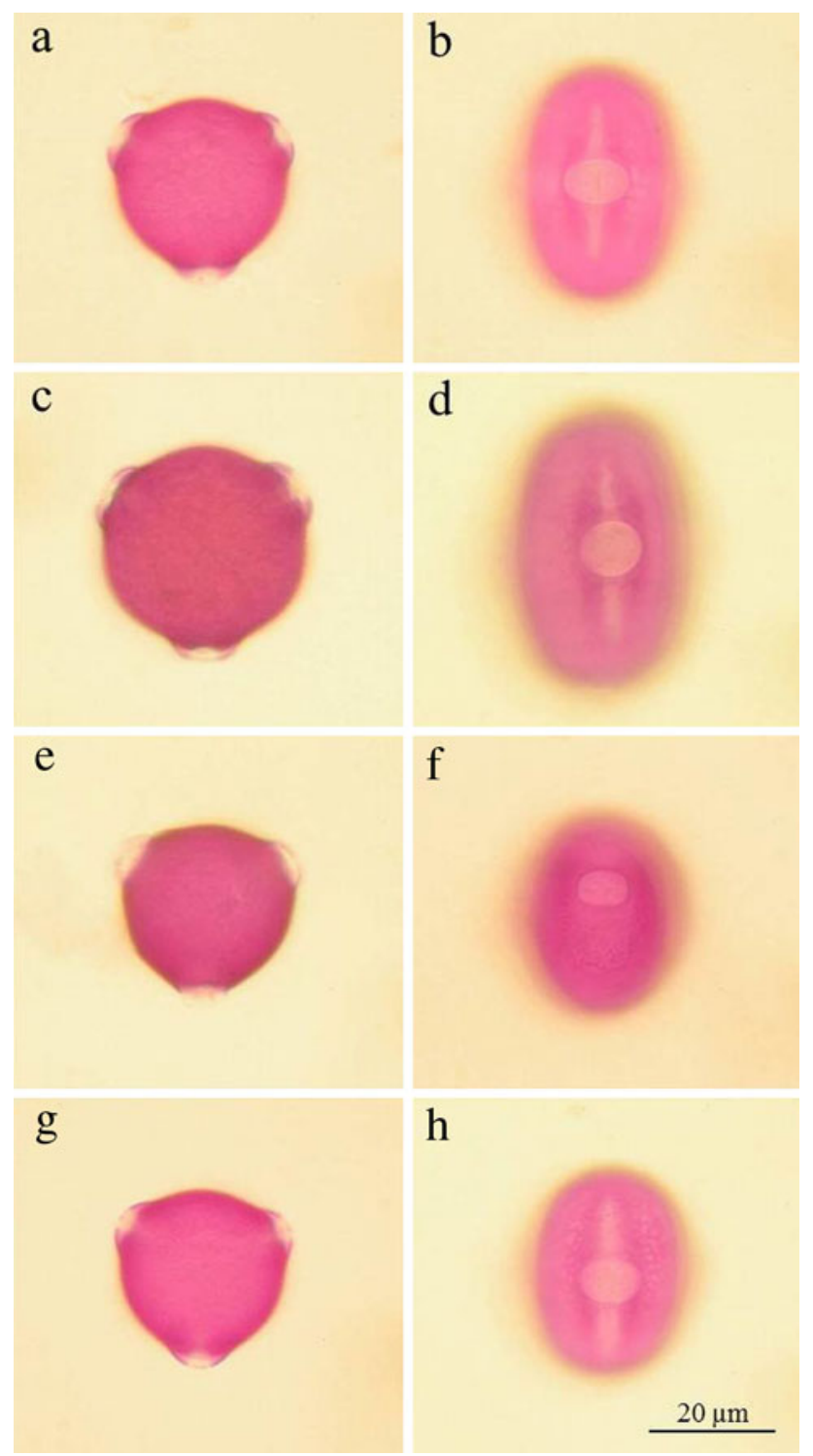

Fig. 1 Pollen grains of examined taxa in LM. a, b Lathyrus rotundifolius subsp. miniatus, $\mathbf{c}, \mathbf{d} L$. grandiflorus, $\mathbf{e}, \mathbf{f} L$. saxatilis, $\mathbf{g}, \mathbf{h} L$. vinealis, $\mathbf{a}, \mathbf{c}, \mathbf{e}, \mathbf{g}$ polar view, $\mathbf{b}, \mathbf{d}, \mathbf{f}, \mathbf{h}$ equatorial view

Pollen type: 3-zonocolporate.

Pollen shape: spheroidal $P / E: 1.03$.

Dimensions: medium size $(P \times E=31.62 \times 30.58 \mu \mathrm{m})$.

Apertures: apertures with an intine protrusion (thickening of the middle of the aperture membrane); ectoapertures-colpi: short, straight, wide, shallow, with obtuse ends, the borders not distinct, same width on pori, clg: $18.08 \mu \mathrm{m}$, clt: $2.37 \mu \mathrm{m}$; endoapertures-pori: small, borders distinct, protruding, lalongate, with an annulus (thickness sexine) and costae (thickness nexine) non-measurable, plg: $7.39 \mu \mathrm{m}$, plt: $8.78 \mu \mathrm{m}$ and plg/plt: 0.84 .

Outlines: equatorial view rectangular-obtuse-emarginate; polar view quinquangular-obtuse-concave.
Ornamentation: mesocolpium area is concave, aperture area and concavity reticulate-granulate in mesocolpium, reticules small, different in size. Outside these areas and the apocolpium are psilate, with polar triangular perforate.

Ex/int: $\cong 1 / 1$.

Exine: $\cong 1.14 \mu \mathrm{m}$.

L. inconspicuus var. stenophyllus (Table 2; Figs. 3c, d, $4 d-f)$

Pollen type: 3-zonocolporate.

Pollen shape: spheroidal P/E: 1.03 .

Dimensions: medium size $(P \times E=31.98 \times 30.99 \mu \mathrm{m})$.

Apertures: apertures with an intine protrusion (thickening of the middle of the aperture membrane); ectoapertures-colpi: short, straight, wide, shallow, with obtuse ends, the borders not distinct, same width on pori, clg: $18.56 \mu \mathrm{m}$, clt: $2.85 \mu \mathrm{m}$; endoapertures-pori: small, borders distinct, protruding, lalongate, with an annulus (thickness sexine) and costae (thickness nexine) non-measurable, plg: $7.18 \mu \mathrm{m}$, plt: $8.76 \mu \mathrm{m}$ and plg/plt: 0.82 .

Outlines: equatorial view rectangular-obtuse-emarginate; polar view quinquangular-obtuse-concave.

Ornamentation: mesocolpium areas are concave, aperture area and concavity reticulate-granulate in mesocolpium, reticules small, different in size. Outside these areas and the apocolpium are psilate, with polar triangular perforate.

Ex/int: $\cong 1 / 1$.

Exine: $\cong 1.14 \mu \mathrm{m}$.

L. tauricola (Table 2; Figs. 3e, f, 4g-i)

Pollen type: 3-zonocolporate.

Pollen shape: spheroidal P/E: 0.99 .

Dimensions: medium size $(P \times E=30.94 \times 31.20 \mu \mathrm{m})$.

Apertures: apertures with an intine protrusion (thickening of the middle of the aperture membrane); ectoapertures-colpi: short, shallow, with obtuse and acute ends, the borders slightly distinct, broader on pori, clg: $16.76 \mu \mathrm{m}$, clt: $4.17 \mu \mathrm{m}$; endoapertures-pori: middle in size, protruding, borders distinct, lalongate, with an annulus (thickness sexine) and costae (thickness nexine) $3.20 \mu \mathrm{m}$, plg: $6.59 \mu \mathrm{m}$, plt: $8.48 \mu \mathrm{m}$ and plg/plt: 0.78 .

Outlines: equatorial view rectangular-obtuse-emarginate; polar view triangular-obtuse-convex.

Ornamentation: mesocolpium areas are concave, aperture area and concavity reticulate-granulate in mesocolpium, reticules small, different in size. Outside these areas and the apocolpium are psilate, with polar triangular perforate.

Ex/int: $\cong 2 / 1$.

Exine: $\cong 1.14 \mu \mathrm{m}$.

L. woronowii (Table 2; Figs. 3g,h, 4k-m)

Pollen type: 3-zonocolporate.

Pollen shape: prolate $P / E: 1.36$.

Dimensions: medium size $(P \times E=35.78 \times 26.31 \mu \mathrm{m})$. 

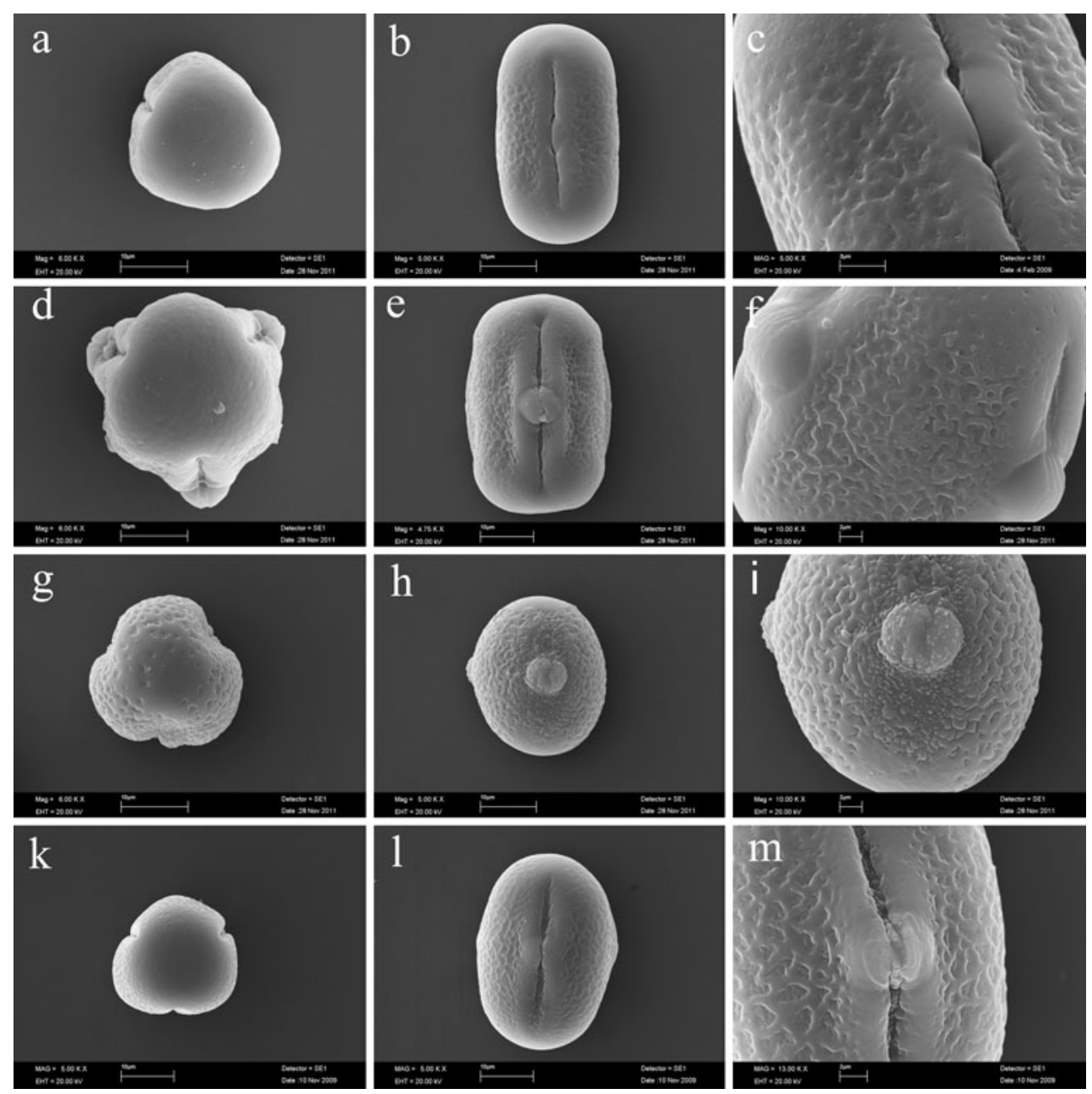

Fig. 2 Pollen grains of examined taxa in SEM. a, b, c Lathyrus rotundifolius subsp. miniatus $\mathbf{d}, \mathbf{e}, \mathbf{f}$ L. grandiflorus, $\mathbf{g}, \mathbf{h}, \mathbf{i}$ L. saxatilis, $\mathbf{k}, \mathbf{l}, \mathbf{m}$ L. vinealis, $\mathbf{a}, \mathbf{d}, \mathbf{g}, \mathbf{k}$ polar view, $\mathbf{b}, \mathbf{e}, \mathbf{h}, \mathbf{l}$ equatorial view, $\mathbf{c}, \mathbf{f}, \mathbf{i}, \mathbf{m}$ ornamentation

Apertures: apertures with an intine protrusion (thickening of the middle of the aperture membrane); ectoapertures-colpi: long, straight, deep, with acute ends, the borders distinct, clg: $26.93 \mu \mathrm{m}$, clt: $4.06 \mu \mathrm{m}$; endoapertures-pori: large, borders distinct, lalongate, with an annulus (thickness sexine) and costae (thickness nexine) $1.14 \mu \mathrm{m}$, plg: $9.05 \mu \mathrm{m}$, plt: $11.42 \mu \mathrm{m}$ and plg/plt: 0.79 .

Outlines: equatorial view rectangular-obtuse-convex; polar view circular to triangular.

Ornamentation: reticulate, reticules big and irregular different in size and shape in the mosocolpium, decreasing towards the apocolpium. Colpus area is psilate. Polar areas are very slightly reticulate.

Ex/int: $\cong 1 / 1$.

Exine: $\cong 1.14 \mu \mathrm{m}$.

L. hierosolymitanus (Table 2; Figs. 5a, b, 6a-c)

Pollen type: 3-zonocolporate.

Pollen shape: spheroidal P/E: 1.07.
Dimensions: medium size $(P \times E=31.20 \times 29.07 \mu \mathrm{m})$.

Apertures: apertures with an intine protrusion (thickening of the middle of the aperture membrane); ectoapertures-colpi: very long, straight, nearly reaching the poles, shallow and wide, with obtuse ends, the borders distinct, widenening on pori in mesocolpium, clg: $30.27 \mu \mathrm{m}$, clt: $4.87 \mu \mathrm{m}$; endoapertures-pori: large, borders distinct, slightly lalongate, with an annulus (thickness sexine) and costae (thickness nexine) thin than $1.14 \mu \mathrm{m}$, plg: $12.32 \mu \mathrm{m}$, plt: $13.22 \mu \mathrm{m}$ and plg/plt: 0.93 .

Outlines: equatorial view elliptic-obtuse-convex; polar view circular to triangular-obtuse-convex.

Ornamentation: reticulate, reticules different in size and shape in the mosocolpium, decreasing towards the apocolpium. The colpus area is psilate, the apocolpium is slightly reticulate.

Ex/int: 1/2.

Exine: $\cong 1.14 \mu \mathrm{m}$. 


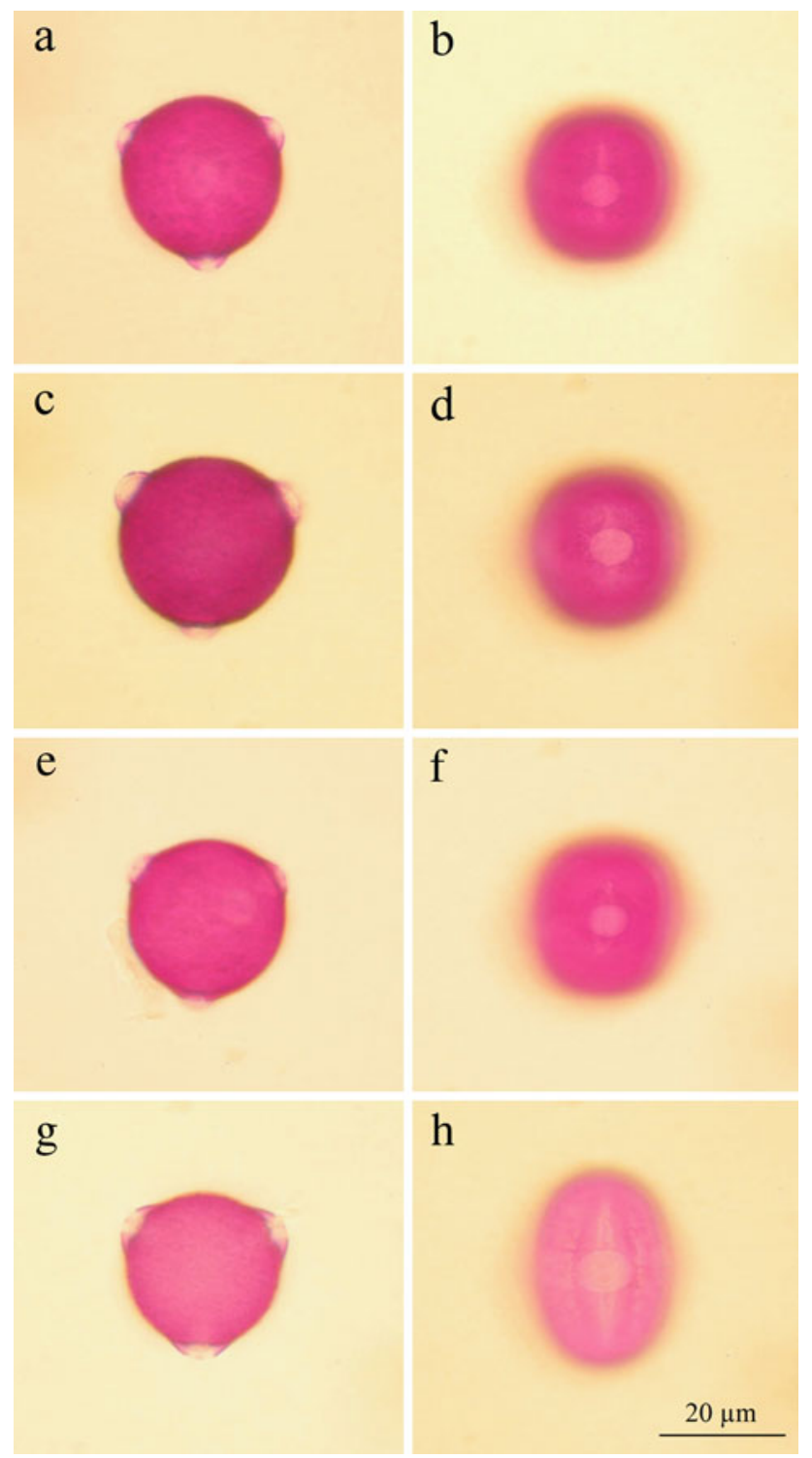

Fig. 3 Pollen grains of examined taxa in LM. a, b Lathyrus inconspicuus var. inconspicuus, $\mathbf{c}, \mathbf{d} L$. inconspicuus var. stenophyllus, $\mathbf{e}, \mathbf{f} L$. tauricola, $\mathbf{g}, \mathbf{h} L$. woronowii, $\mathbf{a}, \mathbf{c}, \mathbf{e}, \mathbf{g}$ polar view, $\mathbf{b}, \mathbf{d}, \mathbf{f}$, $\mathbf{h}$ equatorial view

L. cassius (Table 2; Figs. 5c, d, 6d-f)

Pollen type: 3-zonocolporate.

Pollen shape: prolate $P / E=1.48$.

Dimensions: medium size $(P \times E=44.77 \times 30.11 \mu \mathrm{m})$.

Apertures: apertures with an intine protrusion (thickening of the middle of the aperture membrane); ectoapertures-colpi: long, straight, deep, nearly reaching the poles, borders distinct, broader on pori, with acute ends, clg: $43.37 \mu \mathrm{m}$, clt: $5.85 \mu \mathrm{m}$; endoapertures-pori: large, lalongate, borders distinct, with an thin annulus (thickness sexine) and costae (thickness nexine) $2.28 \mu \mathrm{m}$, plg: $12.71 \mu \mathrm{m}$, plt: $15.65 \mu \mathrm{m}$ and $\mathrm{plg} / \mathrm{plt}=0.81$.
Outlines: equatorial view rectangular-obtuse-convex; polar view triangular to circular.

Ornamentation: reticulate, reticules different in size and shape in the mosocolpium, decreasing towards the apocolpium. The colpus area is psilate. The polar area has small scattered perforations or psilate.

Ex/int: 1/1.

Exine: $\cong 1.14 \mu \mathrm{m}$.

L. gorgoni var. gorgoni (Table 2; Figs. 5e, f, 6,g-i)

Pollen type: 3-zonocolporate.

Pollen shape: subprolate $P / E$ : 1.30 .

Dimensions: medium size $(P \times E=43.89 \times 33.90 \mu \mathrm{m})$.

Apertures: apertures with an intine protrusion (thickening of the middle of the aperture membrane); ectoapertures-colpi: long, straight, deep, shallow and wide, nearly reaching the poles, borders distinct, with acute ends, clg: $39.03 \mu \mathrm{m}$, clt: $3.83 \mu \mathrm{m}$; endoapertures-pori: large, lalongate, borders distinct, protruding, with an annulus (thickness sexine) and costae (thickness nexine) $2.85 \mu \mathrm{m}$, plg: $10.12 \mu \mathrm{m}$, plt: $12.18 \mu \mathrm{m}$ and $\mathrm{plg} / \mathrm{plt}=0.83$.

Outlines: equatorial view elliptic to rectangular-obtuseconvex; polar view circular-obtuse-convex.

Ornamentation: reticulate-granulate, reticules big and irregular, different in size and shape in the mesocolpium. The aperture area is psilate. The apocolpium is slightly reticulate.

Ex/int: $\cong 2 / 1$.

Exine: $\cong 2.28 \mu \mathrm{m}$.

L. pseudo-cicera (Table 2; Figs. 5g, h, 6 k-m)

Pollen type: 3-zonocolporate.

Pollen shape: subprolate $P / E: 1.23$.

Dimensions: medium size $(P \times E=42.43 \times 34.37 \mu \mathrm{m})$.

Apertures: apertures with an intine protrusion (thickening of the middle of the aperture membrane); ectoapertures-colpi: long, straight, deep, borders not distinct, nearly reaching the poles, with acute ends, clg: $36.59 \mu \mathrm{m}$, clt: $4.54 \mu \mathrm{m}$; endoapertures-pori: large, lalongate, borders distinct, with an annulus (thickness exine) and costae (thickness nexine) $2.85 \mu \mathrm{m}$, plg: $8.60 \mu \mathrm{m}$, plt: $12.75 \mu \mathrm{m}$ and plg/plt $=0.67$.

Outlines: equatorial view rectangular-obtuse-convex; polar view circular to triangular-obtuse-convex.

Ornamentation: reticulate-granulate (columellae), reticules different in size and shape in the mesocolpium, decreasing towards the apocolpium. The aperture area is reticulate, the polar area is psilate.

Ex/int: $\cong 1 / 2$.

Exine: $\cong 1.14 \mu \mathrm{m}$.

L. sativus (Table 2; Figs. 7a, b, 8a-c)

Pollen type: 3-zonocolporate.

Pollen shape: subprolate $P / E$ : 1.17 .

Dimensions: medium size $(P \times E=35.01 \times 29.90 \mu \mathrm{m})$.

Apertures: apertures with an intine protrusion (thickening of the middle of the aperture membrane); 
Fig. 4 Pollen grains of examined taxa in SEM. a, b, c Lathyrus inconspicuus var. inconspicuus, $\mathbf{d}, \mathbf{e}$,

f $L$. inconspicuus var. stenophyllus, $\mathbf{g , ~ h , ~ i ~ L . ~ t a u r i c o l a , ~}$ $\mathbf{k}, \mathbf{l}, \mathbf{m}$ L. woronowii, $\mathbf{a}, \mathbf{d}, \mathbf{g}$, $\mathbf{k}$ polar view, $\mathbf{b}, \mathbf{e}, \mathbf{h}, \mathbf{I}$ equatorial view, $\mathbf{c}, \mathbf{f}, \mathbf{i}, \mathbf{m}$ ornamentation
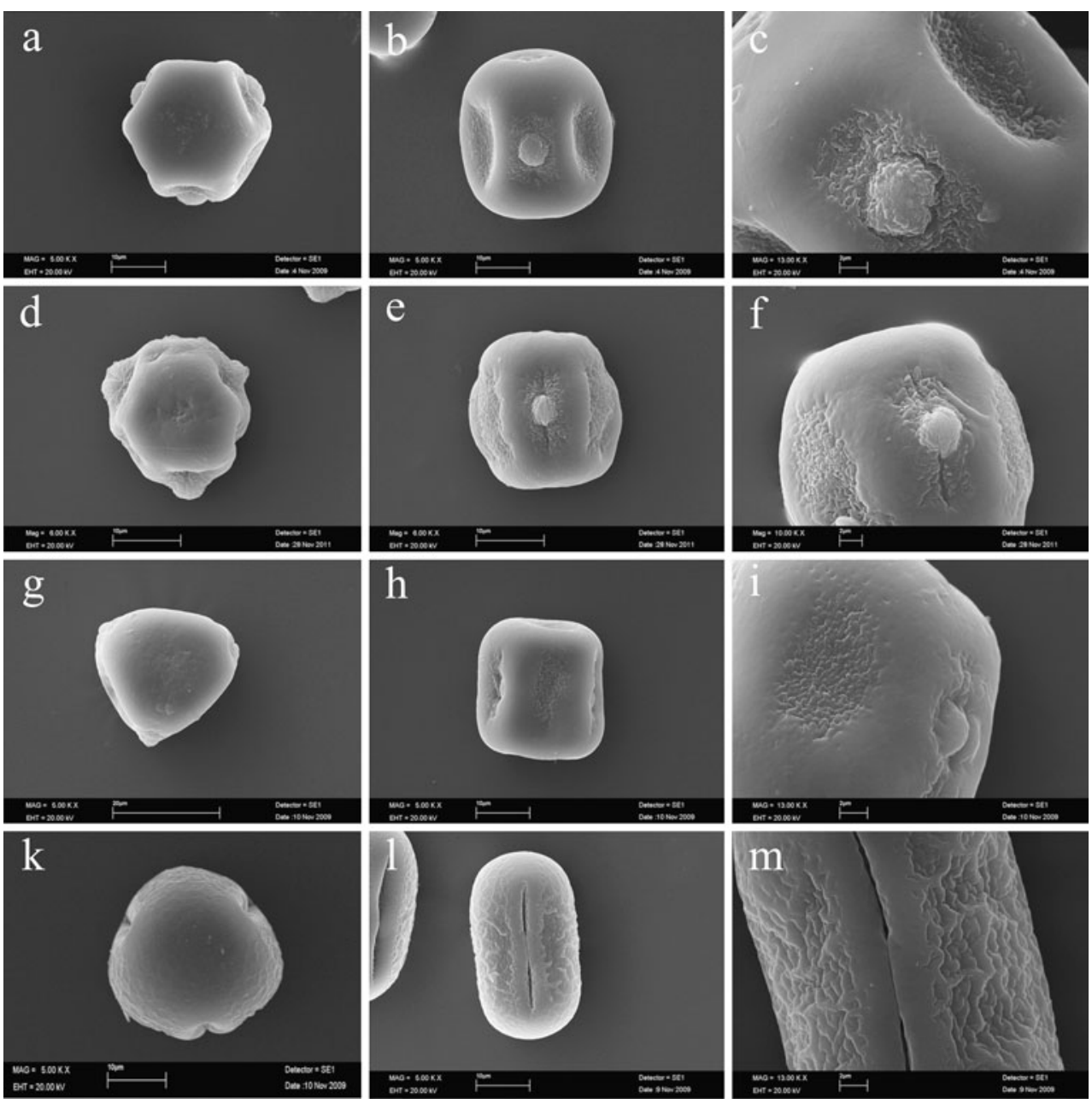

ectoapertures-colpi: long, straight, deep, nearly reaching the poles, borders distinct, with acute ends, widened on pori, clg: $29.42 \mu \mathrm{m}$, clt: $3.24 \mu \mathrm{m}$; endoapertures-pori: large, lalongate, borders distinct, with an annulus (thickness sexine) and costae (thickness nexine) $2.28 \mu \mathrm{m}$, plg: $6.98 \mu \mathrm{m}$, plt: $10.81 \mu \mathrm{m}$ and $\mathrm{plg} / \mathrm{plt}=0.65$.

Outlines: equatorial view elliptical-obtuse-convex; polar view circular to slightly triangular-obtuse-convex.

Ornamentation: reticulate-granulate, reticules are medium in size. The aperture area is psilate, the apocolpium is slightly reticulate-perforate.

Ex/int: $\cong 1 / 2$.

Exine: $\cong 1.14 \mu \mathrm{m}$.

L. blepharicarpus (Table 2; Figs. 7c, d, 8d-f)

Pollen type: 3-zonocolporate.

Pollen shape: subprolate $P / E$ : 1.15 .

Dimensions: medium size $(P \times E=41.65 \times 36.56 \mu \mathrm{m})$.

Apertures: apertures with an intine protrusion (thickening of the middle of the aperture membrane); ectoapertures-colpi: long, straight, shallow to deep, borders less distinct, with acute ends, clg: $34.02 \mu \mathrm{m}$, clt: $3.24 \mu \mathrm{m}$; endoapertures-pori: large, lalongate, borders less distinct, protruding in mesocolpium, with an annulus (thickness sexine) and costae (thickness nexine) $2.85 \mu \mathrm{m}$, plg: $9.51 \mu \mathrm{m}$, plt: $13.36 \mu \mathrm{m}$ and $\mathrm{plg} / \mathrm{plt}=0.71$.

Outlines: equatorial view elliptic-obtuse-convex; polar view circular to slightly triangular-obtuse-convex.

Ornamentation: reticulate-granulate, reticules big and irregular in size and shape. In the mesocolpium, the aperture area is slightly reticulate and not granulate, and the apocolpium is perforate.

Ex/int: $\cong 3 / 1$.

Exine: $\cong 1.14 \mu \mathrm{m}$.

L. stenophyllus (Table 2; Figs. 7e, f, 8g-i).

Pollen type: 3-zonocolporate.

Pollen shape: subprolate $P / E$ : 1.27 .

Dimensions: medium size $(P \times E=47.74 \times 37.64 \mu \mathrm{m})$.

Apertures: apertures with an intine protrusion (thickening of the middle of the aperture membrane); ectoapertures-colpi: long, nearly reaching the poles, borders less 


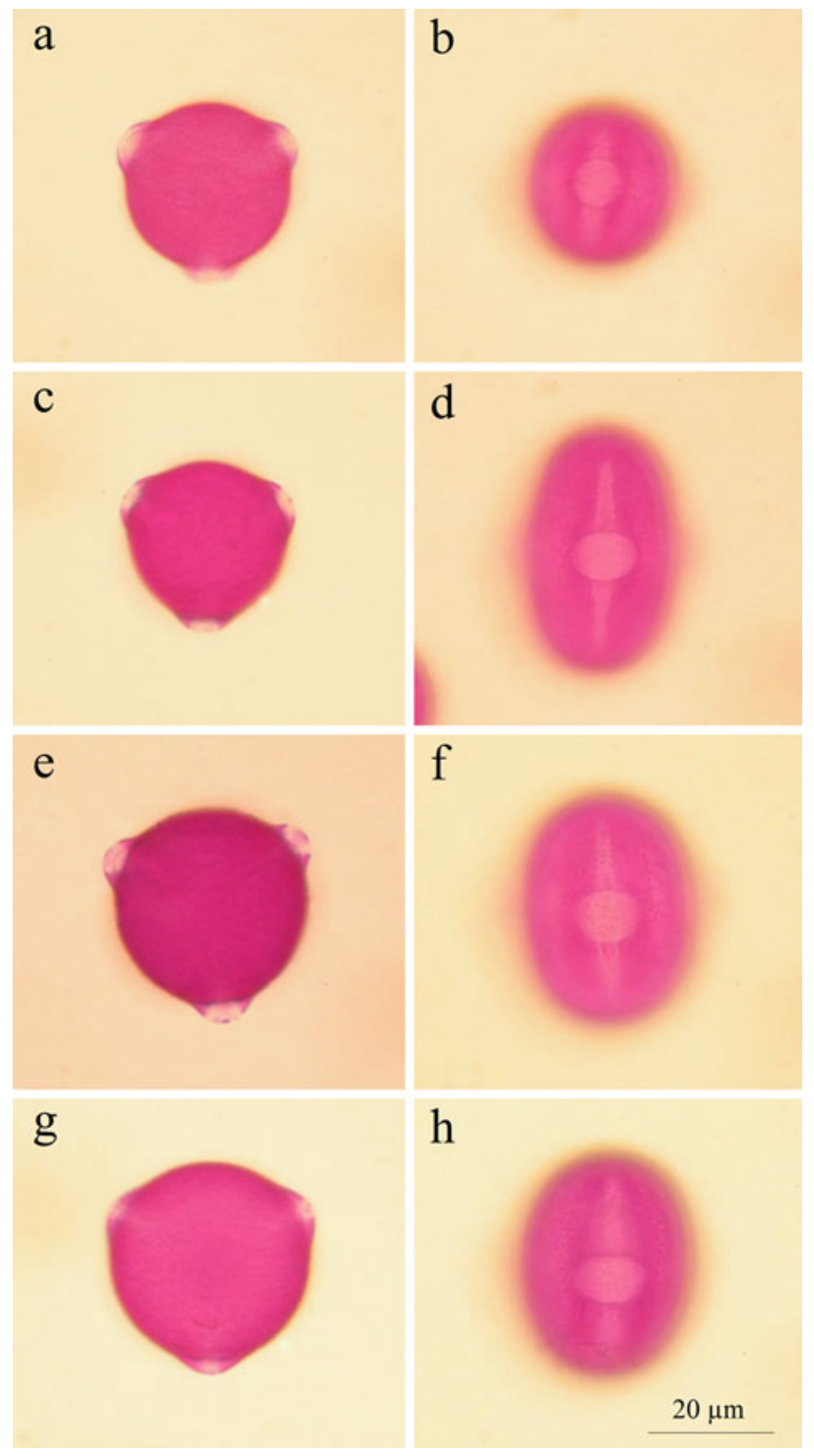

Fig. 5 Pollen grains of examined taxa in LM. a, b Lathyrus hierosolymitanus, $\mathbf{c}, \mathbf{d} L$. cassius, e, $\mathbf{f} L$. gorgoni var. gorgoni, $\mathbf{g}$, $\mathbf{h} L$. pseudo-cicera, a, $\mathbf{c}, \mathbf{e}, \mathbf{g}$ polar view $\mathbf{b}, \mathbf{d}, \mathbf{f}, \mathbf{h}$ equatorial view

distinct, wide, deep, with acute ends, clg: $38.05 \mu \mathrm{m}$, clt: $4.93 \mu \mathrm{m}$; endoapertures-pori: large, lalongate, borders distinct, with an thin annulus (thickness sexine) and costae (thickness nexine) $2.5 \mu \mathrm{m}$, plg: $10.40 \mu \mathrm{m}$, plt: $11.72 \mu \mathrm{m}$ and $\mathrm{plg} / \mathrm{plt}=0.89$.

Outlines: equatorial view rectangular-obtuse-convex; polar view circular to triangular-obtuse-convex.

Ornamentation: Reticulate-slightly granulate, reticules big and irregular in size and shape. In the mesocolpium, the aperture area is psilate, and the apocolpium is slightly reticulate-granulate.

$\mathrm{Ex} / \mathrm{int}: \cong 2 / 1$.

Exine: $\cong 2.28 \mu \mathrm{m}$.
L. belinensis (Table 2; Figs. 7g, h, 8k-m)

Pollen type: 3-zonocolporate.

Pollen shape: subprolate $P / E$ : 1.25 .

Dimensions: medium size $(P \times E=45.24 \times 36.17 \mu \mathrm{m})$.

Apertures: apertures with an intine protrusion (thickening of the middle of the aperture membrane); ectoapertures-colpi: long, straight, borders distinct, narrow, deep, with acute ends, clg: $28.70 \mu \mathrm{m}$, clt: $1.85 \mu \mathrm{m}$; endoapertures-pori: large, lalongate, borders distinct, with an annulus (thickness sexine) and costae (thickness nexine) $2.19 \mu \mathrm{m}$, plg: $10.68 \mu \mathrm{m}$, plt: $13.25 \mu \mathrm{m}$ and $\mathrm{plg} / \mathrm{plt}=0.81$.

Outlines: equatorial view rectangular-obtuse-convex; polar view circular to quiguangular-obtuse-convex.

Ornamentation: reticulate, reticules big and different in size and shape, distinct to less distinct in the mesocolpium. The aperture areas are psilate, and the apocolpium is slightly perforate.

Ex/int: $2 / 1$.

Exine: $\cong 1.14 \mu \mathrm{m}$.

L. phaselitanus (Table 2; Figs. 9a, b, 10a-c)

Pollen type: 3-zonocolporate.

Pollen shape: subprolate $P / E: 1.24$

Dimensions: medium size $(P \times E=37.05 \times 28.89 \mu \mathrm{m})$.

Apertures: apertures with an intine protrusion (thickening of the middle of the aperture membrane); ectoapertures-colpi: long, straight, borders distinct, shallow to deep, broader on the pori, with acute ends, clg: $29.42 \mu \mathrm{m}$, clt: $2.23 \mu \mathrm{m}$; endoapertures-pori: not large, lalongate, borders distinct, with an thin annulus (thickness sexine) and costae (thickness nexine) $2.85 \mu \mathrm{m}$, plg: $8.28 \mu \mathrm{m}$, plt: $10.49 \mu \mathrm{m}$ and $\mathrm{plg} / \mathrm{plt}=0.79$.

Outlines: equatorial view rectangular-obtuse-convex; polar view triangular.

Ornamentation: slightly reticulate to psilate, reticules are different in size in the mesocolpium. The aperture area and apocolpium are psilate.

Ex/int: $2 / 1$.

Exine: $\cong 1.14 \mu \mathrm{m}$.

L. chrysanthus (Table 2; Figs. 9c, d, 10d-f)

Pollen type: 3-zonocolporate.

Pollen shape: subprolate $P / E$ : 1.28 .

Dimensions: medium size $(P \times E=44.20 \times 34.43 \mu \mathrm{m})$.

Apertures: apertures with an intine protrusion (thickening of the middle of the aperture membrane); ectoapertures-colpi: not long, straight, borders distinct, deep, same width in the mesocolpium (on pori), with acute ends, clg: $30.48 \mu \mathrm{m}$, clt: $2.12 \mu \mathrm{m}$; endoapertures-pori: large, lalongate, borders distinct, protruding or not in mesocolpium, with an annulus (thickness sexine) and heavy thick costae (thickness nexine) $4.10 \mu \mathrm{m}$, plg: $8.16 \mu \mathrm{m}$, plt: $9.92 \mu \mathrm{m}$ and $\mathrm{plg} / \mathrm{plt}=0.82$.

Outlines: equatorial view rectangular-obtuse-convex; polar view triangular to circular. 

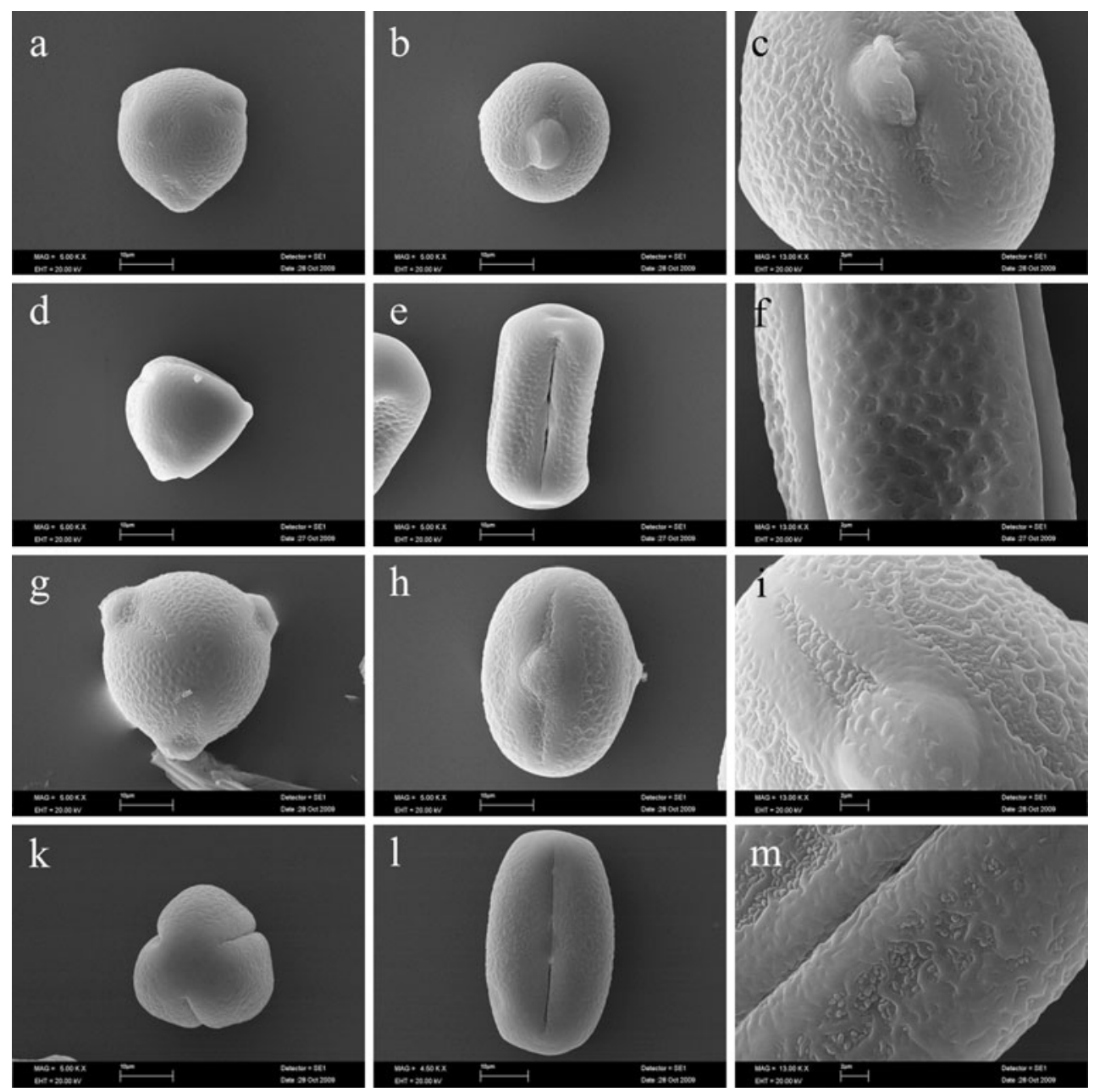

Fig. 6 Pollen grains of examined taxa in SEM. a, b, c Lathyrus hierosolymitanus, d, e, f L. cassius, $\mathbf{g}, \mathbf{h}, \mathbf{i}$ L. gorgoni var. gorgoni, $\mathbf{k}, \mathbf{l}, \mathbf{m} L$. pseudo-cicera, $\mathbf{a}, \mathbf{d}, \mathbf{g}, \mathbf{k}$ polar view, $\mathbf{b}, \mathbf{e}, \mathbf{h}, \mathbf{l}$ equatorial view, $\mathbf{c}, \mathbf{f}, \mathbf{i}, \mathbf{m}$ ornamentation

Ornamentation: reticulate; reticules are different in size and shape in the mesocolpium. The aperture area and apocolpium are psilate.

Ex/int: $\cong 2 / 1$.

Exine: $\cong 0.57 \mu \mathrm{m}$.

L. chloranthus (Table 2; Figs. 9e, f, 10g-i)

Pollen type: 3-zonocolporate.

Pollen shape: subprolate $P / E$ : 1.26 .

Dimensions: medium size $(P \times E=39.68 \times 31.56 \mu \mathrm{m})$.

Apertures: apertures with an intine protrusion (thickening of the middle of the aperture membrane); ectoapertures-colpi: long, straight, wide, deep, nearly reaching the poles, borders not distinct, same width on pori, with acute ends, clg: $35.98 \mu \mathrm{m}$, clt: $6.02 \mu \mathrm{m}$; endoapertures-pori: large, lalongate, borders distinct, with an annulus (thickness sexine) and costae (thickness nexine) $1.71 \mu \mathrm{m}$, plg: $9.78 \mu \mathrm{m}$, plt: $11.13 \mu \mathrm{m}$ and $\mathrm{plg} / \mathrm{plt}=0.88$.
Outlines: equatorial view rectangular-obtuse-convex; polar view triangular to circular.

Ornamentation: distinct reticulate, reticules big, different in size and shape in the mesocolpium. The aperture area is psilate, and the apocolpium is slightly perforate.

$\mathrm{Ex} / \mathrm{int}: \cong 1 / 2$.

Exine: $\cong 0.57 \mu \mathrm{m}$.

L. trachycarpus (Table 2; Figs. 9g, h, 10k-m)

Pollen type: 3-zonocolporate.

Pollen shape: subprolate to prolate $P / E: 1.33$.

Dimensions: medium size $(P \times E=43.78 \times 32.86 \mu \mathrm{m})$.

Apertures: apertures with an intine protrusion (thickening of the middle of the aperture membrane); ectoapertures-colpi: not long, not straight, borders distinct, deep, same width on pori, with acute ends, clg: $29.71 \mu \mathrm{m}$, clt: $2.92 \mu \mathrm{m}$; endoapertures-pori: large, lalongate, borders distinct, with an thick annulus (thickness sexine) and costae 


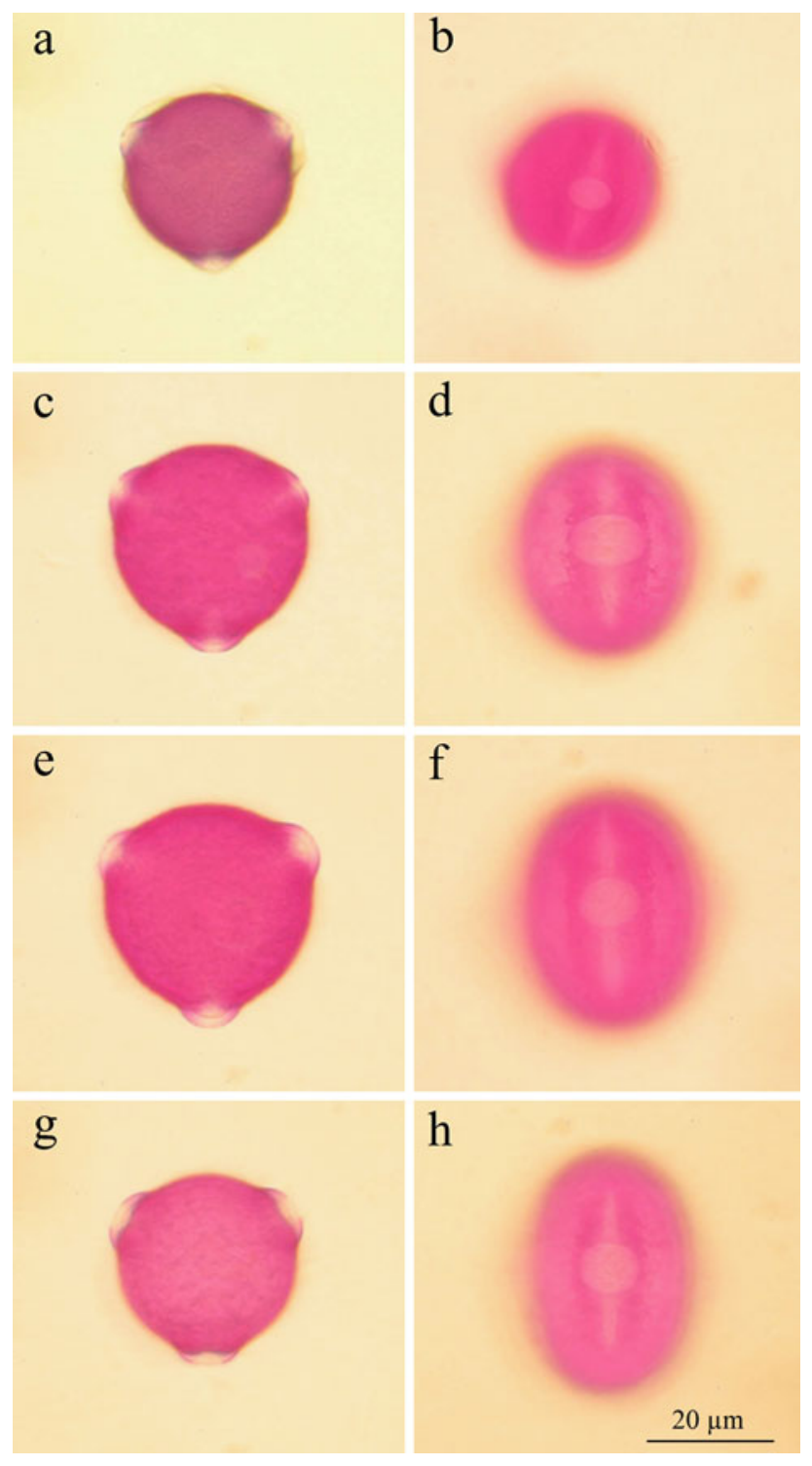

Fig. 7 Pollen grains of examined taxa in LM. a, b Lathyrus sativus, $\mathbf{c}, \mathbf{d}$ L. blepharicarpus, $\mathbf{e}, \mathbf{f}$ L. stenophyllus, $\mathbf{g}, \mathbf{h}$ L. belinensis, a, c, e, $\mathbf{g}$ polar view, $\mathbf{b}, \mathbf{d}, \mathbf{f}, \mathbf{h}$ equatorial view

(thickness nexine) $2.85 \mu \mathrm{m}$, plg: $10.44 \mu \mathrm{m}$, plt: $12.84 \mu \mathrm{m}$ and $\mathrm{plg} / \mathrm{plt}=0.81$.

Outlines: equatorial view rectangular-obtuse-convex; polar view triangular.

Ornamentation: slightly reticulate, reticules are different in size and shape in the mesocolpium. The aperture area and apocolpium are psilate.

Ex/int: $\cong 1 / 2$.

Exine: $\cong 0.57 \mu \mathrm{m}$.

The pollen grains of the analysed taxa were divided into groups according to their equatorial view and shape as follows:
According to the equatorial view:

\section{Section Lathyrus}

1. Rectangular: L. rotundifolius subsp. miniatus, L. grandiflorus, L. undulatus, L. sylvestris

2. Elliptical: L. tuberosus

\section{Section Orobastrum}

1. Elliptical: L. saxatilis, L. sphaericus, L. setifolius

2. Rectangular: $L$. vinealis, $L$. woronowii

3. Rectangular-emarginate: L. inconspicuus var. inconspicuus, L. inconspicuus var. stenophyllus, L. tauricola.

\section{Section Cicercula}

1. Elliptical: L. annuus, L. hierosolymitanus, L. sativus, L. blepharicarpus,

2. Elliptical to rectangular: L. gorgoni var. gorgoni, $L$. gorgoni var. pilosus, $L$. cicera, L. hirsutus

3. Rectangular: L. cassius, L. pseudo-cicera, L. stenophyllus, L. belinensis, L. phaselitanus, L. chrysanthus, L. chloranthus, L. trachycarpus,

According to pollen shape:

\section{Section Lathyrus}

1. Spheroidal: L. tuberosus

2. Subprolate: L. rotundifolius subsp. miniatus, $L$. undulatus, L. sylvestris

3. Prolate: L. grandiflorus

\section{Section Orobastrum}

1. Spheroidal: $L$. inconspicuus var. inconspicuus, $L$. inconspicuus var. stenophyllus, $L$. tauricola, $L$. sphaericus, L. setifolius

2. Subprolate: $L$. saxatilis, $L$. vinealis

3. Prolate:, L. woronowii

\section{Section Cicercula}

1. Spheroidal: L. annuus, L. hierosolymitanus

2. Subprolate: L. gorgoni var. pilosus, L. gorgoni var. gorgoni, L. pseudo-cicera, L. cicera, L. sativus, L. blepharicarpus, L. stenophyllus, L. belinensis, L. phaselitanus, L. hirsurus, L. chrysanthus, L. chloranthus

3. Subprolate to Prolate: L. trachycarpus

4. Prolate: L. cassius

The aperture system: intine protrusion and distinct annulus above the apertures. Ectoapertures-colpi: usually long, straight, borders distinct or not, shallow or deep, narrow or wide, usually with acute ends. Endoapertures- 

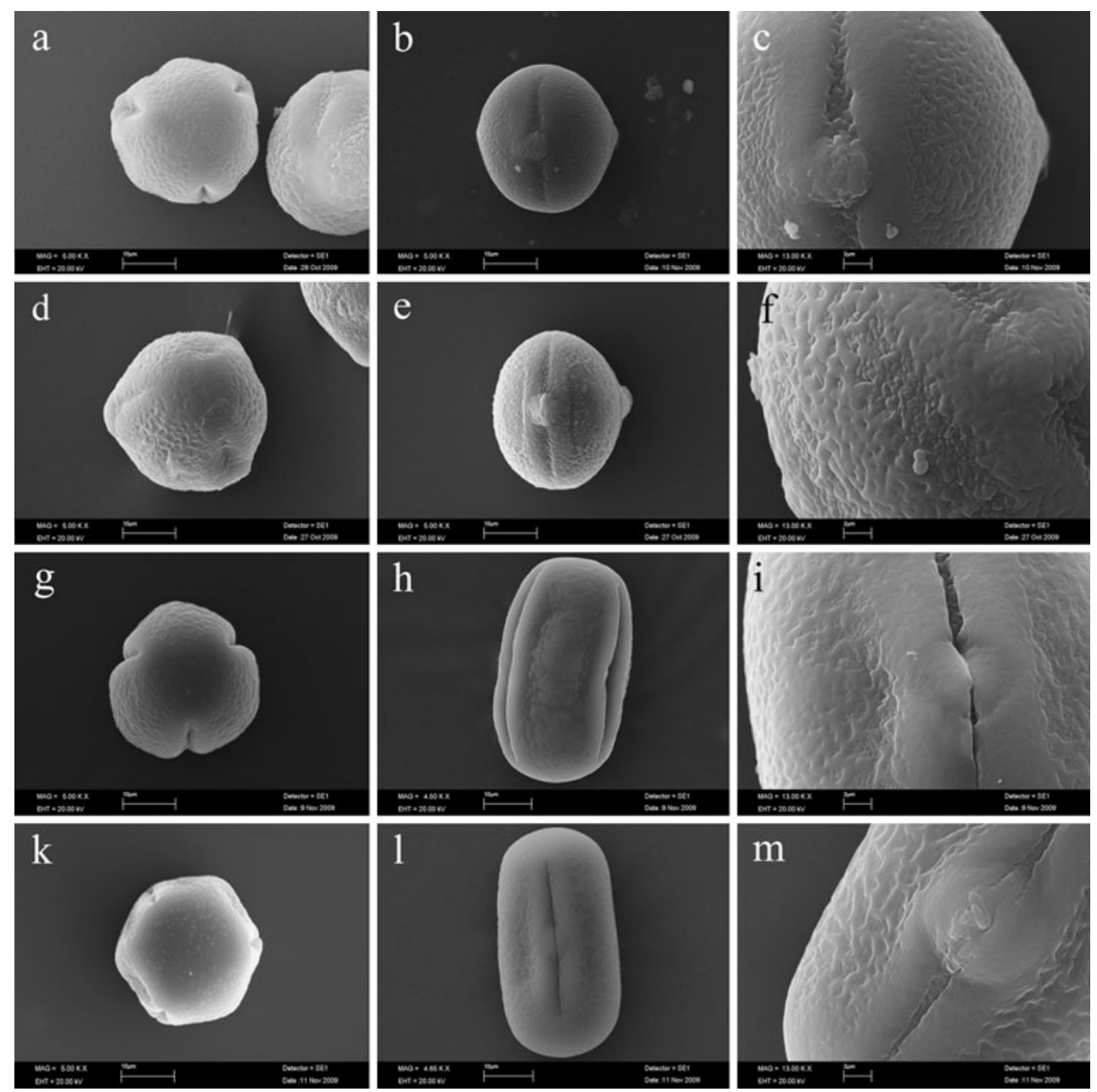

Fig. 8 Pollen grains of examined taxa in SEM. a, b, c Lathyrus sativus, $\mathbf{d}, \mathbf{e}, \mathbf{f}$ L. blepharicarpus, $\mathbf{g}, \mathbf{h}, \mathbf{i}$ L. stenophyllus, $\mathbf{k}, \mathbf{l}, \mathbf{m}$ L. belinensis, $\mathbf{a}$, $\mathbf{d}, \mathbf{g}, \mathbf{k}$ polar view, $\mathbf{b}, \mathbf{e}, \mathbf{h}, \mathbf{l}$ equatorial view, $\mathbf{c}, \mathbf{f}, \mathbf{i}, \mathbf{m}$ ornamentation

pori: large, lalongate, borders distinct, protruding in the mesocolpium or not.

Exine; tectate-infrastructure and exine thickness ranged between 0.57 and $2.28 \mu \mathrm{m}$. The thickest exine was observed in L. saxatilis, L. gorgoni var. gorgoni, and $L$. stenophyllus, and the thinnest exine was observed in $L$. chrysanthus, L. chloranthus, and L. trachycarpus.

The ornamentation was reticulate, reticulate-granulate, or slightly reticulate in the mosocolpium. The apocolpium and the aperture area were usually psilate.

\section{Discussion}

With this study, the pollen morphology of the 63 taxa that have spread in Turkey up to the present day has been determined (Aytug et al. 1971; Günes and Cirpici 1998, 2010; Günes and Aytug 2010; Güneş 2011a, b; Çildir 2011; Kahraman et al. 2012). This number comprises about $85 \%$ of all species of Lathyrus in Turkey. Of the 63 taxa, the pollen morphologies have been determined, with the largest pollen originating from $L$. clymenum $(P=52.42$; $E=35.82 \mu \mathrm{m}$, prolate $)$ and $L$. ochrus $(P=52.66$; $E=33.02 \mu \mathrm{m}$, prolate), and the smallest pollen found in the $L$. tauricola $(P=30.94 ; E=31.20 \mu \mathrm{m}$, spheroidal $), L$. inconspicuus var. inconspicuus $(P=31.62 ; \quad E=$ $30.58 \mu \mathrm{m}$, spheroidal) and L. inconspicuus var. stenophyllus $(P=31.98 ; E=30.99 \mu \mathrm{m}$, spheroidal) taxa. This shows that the largest pollen samples were observed in the Clymenum section, and the smallest pollen types were observed in the Orobastrum sections. Pollen of the monotypic species of L. nissolia in the Nissolia section ( $P=32.79 ; E=24.75 \mu \mathrm{m}$, subprolate to prolate) was small and similar to those in the Orobastrum section. The smallest pollen in the Pratensis section belongs to $L$. pratensis $(P=36.83 ; E=29.75 \mu \mathrm{m}$, subprolate), and the largest pollen belongs to the L. czeczottianus $(P=43.08$; $E=31.20 \mu \mathrm{m}$, prolate) taxon (Günes and Aytug 2010), whereas the smallest pollen in the Platystylis section belongs to $L$. elongates $(P=36.97 ; E=38.64 \mu \mathrm{m}$, 


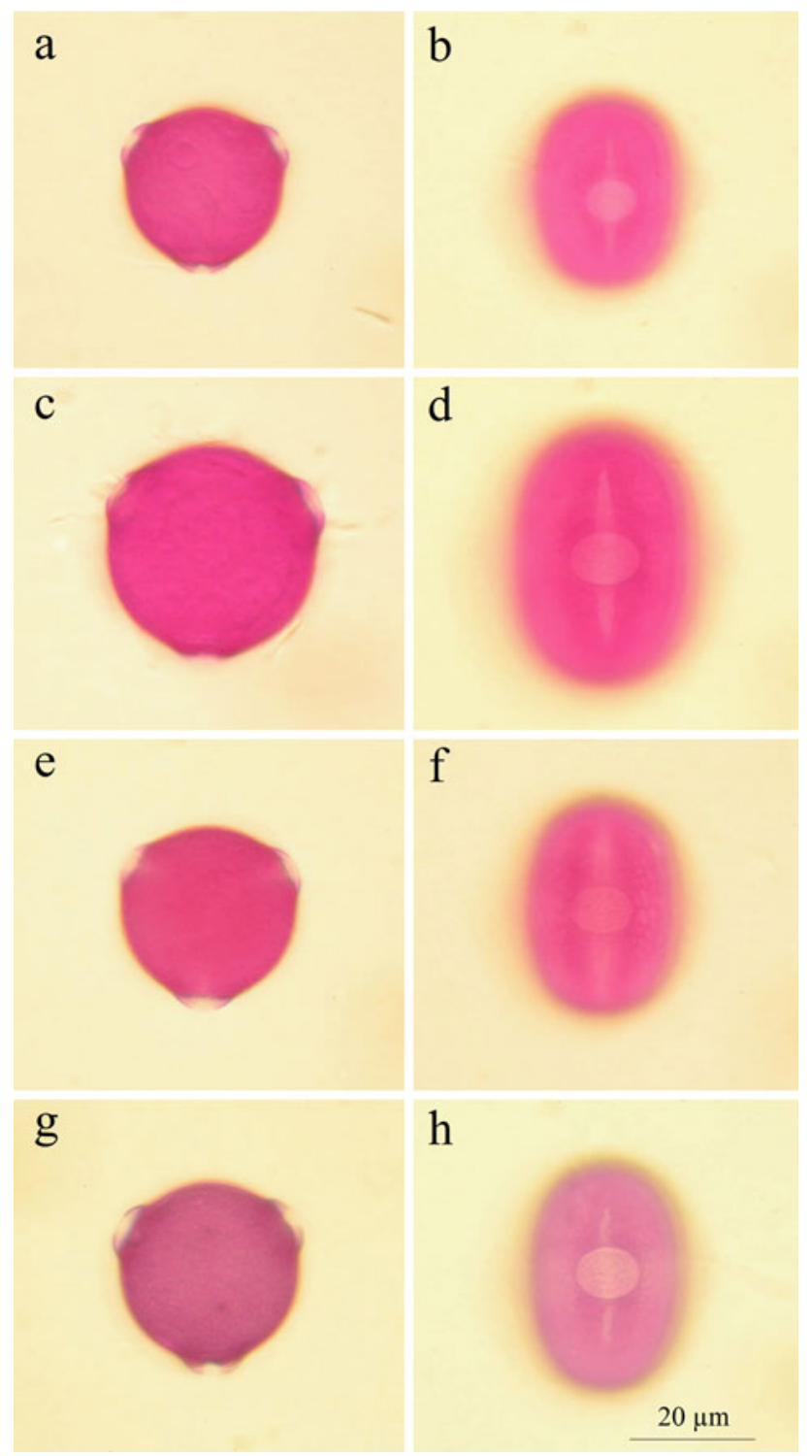

Fig. 9 Pollen grains of examined taxa in LM. a, b Lathyrus phaselitanus, c, d L. chrysanthus, e, f L. chloranthus, $\mathbf{g}, \mathbf{h} L$. trachycarpus, a, c, e, $\mathbf{g}$ polar view, $\mathbf{b}, \mathbf{d}, \mathbf{f}, \mathbf{h}$ equatorial view

spheroidal), and the largest pollen belongs to the L. cyaneus var. cyaneus $(P=46.33 ; E=32.86 \mu \mathrm{m}$, prolate) taxon (Güneş 2011a). The smallest pollen in the Lathyrus section was from the $L$. tuberosus $(P=34.69$; $E=31.72 \mu \mathrm{m}$, spheroidal) (Güneş 2011b), whereas the largest pollen was from the $L$. grandiflorus $(P=50.60$; $E=36.40 \mu \mathrm{m}$, prolate) taxon; the smallest pollen in section Orobastrum was from $L$. tauricola $(P=30.94$; $E=31.20 \mu \mathrm{m}$, spheroidal), whereas the largest pollen was from $L$. saxatilis $(P=37.24 ; E=30.41 \mu \mathrm{m}$, subprolate); the smallest pollen in section Cicercula was from $L$. hierosolymitanus $(P=31.20 ; E=29.07 \mu \mathrm{m}$, spheroidal $)$, while the largest pollen was from L. stenophyllus ( $P=47.74 ; E=37.64 \mu \mathrm{m}$, subprolate) taxon.

Moore et al. (1991) determined the Lathyrus pollen grains as the Vicia cracca type (e.g., L. montanus), the Vicia sylvatica type (e.g. L. sylvestris), or the Lathyrus type (e.g. L. pratensis). Tosheva and Tonkov, additionally, found the Lathyrus filiformis type, which is a fourth type in section Platystylis, and L. inconspicuus var. inconspicuus, L. inconspicuus var. stenophyllus, and L. tauricola taxa. Outside of Turkey, the Lathyrus taxa has been rarely analysed until now (Gapotchka and Chamara 1972; Gapotchka 1974; Faegri and Iversen 1989; Tosheva et al. 2004; Tosheva and Tonkov 2005, 2007). The pollen of L. grandiflorus $(P \times E=47.4$ (58.6) $66.4 \times 39.5$ (46.3) $53.7 \mu \mathrm{m}$, subprolate) was identified as the largest pollen by Tosheva et al. (2004). The results of the current study suggest that the pollen here is greater and the shape is different when compared with their values (Table 2).

While the pollen morphological properties of all taxa in sections Platystylis, Pratensis, Lathyrus, Orobastrum and Nissolia that are found naturally in Turkey have been determined, the pollen morphological properties of a total of 11 taxa in the Orobus, Orobon, Cicercula, Clymenum, and Aphaca sections have not yet been determined. When the Lathyrus pollen are evaluated in general, the pollen are mostly of the type Vicia cracca, V. sylvatica, Lathyrus, and L. filiformis, with Lathyrus and V. sylvatica types observed the most. Seventeen taxa have spheroidal pollen, whereas 35 taxa have subprolate and 11 taxa have prolate-shaped pollen. The colpi is generally long and flat, while the porus is large and lalongate. The equatorial view is generally elliptical to rectangular; the polar view is circular, triangular, and quinquangular (as L. inconspicuus var. inconspicuus, L. inconspicuus var. stenophyllus, L. tauricola). The structures are tectate infrastructure, sculpture (ornamentation); reticulate, reticulate-granulate or reticulateperforate; and the size and arrangement of the reticules along the stem, as well as whether they are more distinct or not, differ with respect to the species.

When the pollen morphologies of L. saxatilis, L. cassius, $L$. chrysanthus, and $L$. trachycarpus taxa are examined, amorphous-shaped pollen with 3-4-5 pores and colpus with different shapes have been observed (within the preparations from the species collected from the other localities a total of 3-4 multi-porus and colpus types of pollen were observed). The ratio of the amorphous pollen is about $20 \%$. It is thought that there are various abnormalities in the pollen embryological developments of these species, and it has been observed in $L$. grandiflorus, $L$. saxatilis, $L$. sativus, L. blepharicarpus, and L. belinensis that the pollen germinated in the preparates. No remarkable distinctions were found when analysing the samples of the other taxa 

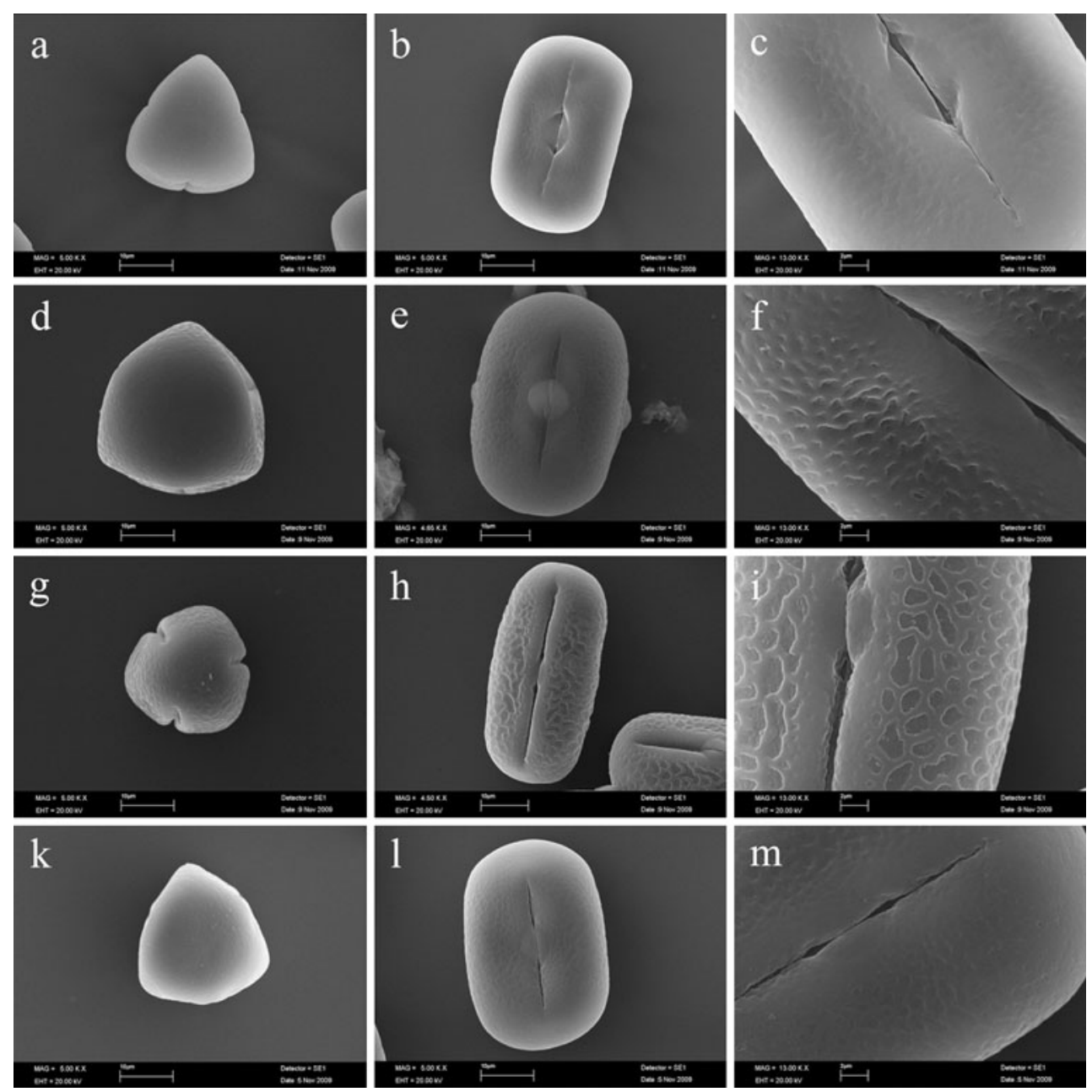

Fig. 10 Pollen grains of examined taxa in SEM. a, b, c Lathyrus phaselitanus, d, e, f L. chrysanthus, g, h, i L. chloranthus, $\mathbf{k}, \mathbf{l}, \mathbf{m} L$. trachycarpus, $\mathbf{a}, \mathbf{d}, \mathbf{g}, \mathbf{k}$ polar view, $\mathbf{b}, \mathbf{e}, \mathbf{h}, \mathbf{l}$ equatorial view, $\mathbf{c}, \mathbf{f}, \mathbf{i}, \mathbf{m}$ ornamentation

collected from the different localities. Pollen characteristics are not affected by geographical changes (Aytug 1959).

When the results are compared with those obtained by Kahraman et al. (2012), it is seen that the pollen dimension findings for $L$. chloranthus $(P \times E=46.82 \times 37.16 \mu \mathrm{m})$ are larger than those in our study, whereas the colpus length (clg) of $L$. inconspicuous is longer $(27.78 \mu \mathrm{m})$, the clg of $L$. saxatilis is longer, and the plg and plt values are smaller (Table 2).

Cronquist (1968) reported that pollen sculpture types have valid morphological features in taxonomy. Thus, the taxonomic value of these Lathyrus taxa, as well as their pollen morphology, could be a distinguishing criterion. In conclusion, the morphological structures of pollen seem to be useful for differentiating between taxa; thus, it is suggested that they could be of benefit in taxonomical studies.

Acknowledgments The author gives thanks to "The Scientific and Technological Research Council of Turkey" for financial support (project number 10T127) and managers of ANK, ATA, EDTU, EGE, FUH, GAZI, HUB, ISTE, ISTF, ISTO, KATU, MUFE, NGBB, and KNYF for making some materials available. I am also grateful to the authorities of the Erciyes University Technology Research and Development Centre for the SEM analysis of the pollen.

Open Access This article is distributed under the terms of the Creative Commons Attribution License which permits any use, distribution, and reproduction in any medium, provided the original author(s) and the source are credited.

\section{References}

Aytug B (1959) Role of Palinology in Taxonomy and Classification (in Turkish). J For Fac İstanbul Univ Ser B 9:118-125, İstanbul, Turkey Aytug B, Aykut S, Merev N, Edis G (1971) Pollen atlas of plants from environs of İstanbul (in Turkish). Yayin 1654/174, Kurtulmuş matbaas1, İstanbul, Turkey

Ball PW (1968) Lathyrus L. In: Tutin et al (eds) "Flora Europaea", vol 2. Cambridge Univ. Press, London, pp 136-143 
Bässler M (1980) Revision von Lathyrus L. sect. Lathyrostylis (Griseb.) Bässler (Fabaceae). Feddes Report 90:210-241

Campbell CG (1997) Grass pea. Lathyrus sativus L. promoting the conservation and use of underutilized and neglected crops. 18. Institute of Plant Genetics Crops, Germany

Çildir H (2011) Morphology, anatomy and systematics of the genus Lathyrus L. (Leguminosae) in Central Anatolia, Turkey. Ph.D. Thesis. Departmet of Biology, Middle East Technical University, Ankara, Turkey

Cronquist A (1968) The evolution and classification of the flowering plants. Thomas Nelson Ltd, Edinburgh

Dakijordanov A (1976) Flora of Bulgaria, vol 6. Erdicae, Bulgaria, pp 503-547

Davis PH (1970) Lathyrus L. In: Davis PH (ed) Flora of Turkey, vol 3. University Press, Edinburgh

Davis PH (1988) Flora of Turkey, vol 10. University Press, Edinburgh

Faegri K, Iversen J (1989) Textbook of pollen analysis. Blackwell, Chichester

Fedchenko BA (1948) Lathyrus L. In: Komarov VL, Shishkin BK, Bobrov EG (eds) Flora of the USSR, vol 13. Leguminosae: Oxytropis, Hedysarum. Leningrad: Izdatelstvo Akademii Nauk SSSR, Mosqua, pp 363-395

Gapotchka GP (1974) On the palynomorphology of the species of the tribe Vicieae from the family Fabaceae. Vest. Mosk. Univ ser 6 Biol 29:93-98

Gapotchka GP, Chamara LP (1972) The development of sporoderma in Lathyrus niger (L.) Bernh. Vest. Mosk. Unv. ser. 6 Bio 27:50-54

Güneş F (2006) The ethnobotanical importance of some Lathyrus (Fabaceae) species. In: Proceedings of the IVth international congress of ethnobotany (ICEB 2005). Efe yayınları, İstanbul, pp 585-588

Güneş F (2011a) Pollen morphology of Lathyrus (Fabaceae) taxa in the Platystylis section from Turkey. Plant Syst Evol 293:75-90

Güneş F (2011b) The pollen morphology of some Lathyrus Spp (Fabaceae) taxa from Turkey. Int J Agric Biol 13(3):301-308

Güneş F, Aytug B (2010) Pollen morphology of the genus Lathyrus (Fabaceae) section Pratensis in Turkey. Int $\mathrm{J}$ Agric Biol 12:96-100

Güneş F, Cirpici A (1998) Pollen morphology of some Lathyrus species (L. undulatus Boiss., L. sylvestris L., L. ochrus (L.) DC) of Istanbul area (In Tukish). In: Proceedings of the Symposium on Quercus vulcanica and Flora of Turkey, Çantay Kitapevi, Laleli-Istanbul, pp 431-440

Güneş F, Cirpici A (2010) Pollen morphology of the genus Lathyrus (Fabaceae) section Cicercula in Thrace (European Turkey). Acta Bot Croat 69(1):83-92
Güneş F, Özhatay N (2000) Lathyrus L. In: Güner A, Özhatay N, Ekim T, Başer KHC (eds) Flora of Turkey and the East Aegean Islands, vol 11. Edinburgh University Press, Edinburgh, pp 92-94

Kahraman A, Çildir H, Doğan M, Güneş F, Celep F (2012) Pollen morphology of Lathyrus taxa (Fabaceae) and its systematic implications. Aust J Crop Sci (AJCS) 6(2):223-226

Kupicha FK (1983) The infrageneric structure of Lathyrus notes from the royal botanic garden Edinburgh 41:209-244

Meikle RD (1977) Lathyrus to Flora of Cyprus, the bentham-moxon trust royal botanic gardens. Kew, pp 556-578

Moore PD, Webb JA, Collinson M (1991) Pollen analysis. Blackwell Science Publication, London

Perveen A, Qaiser M (1998) Pollen flora of Pakistan, 8. Leguninosae (subfamly: papilionoideae). Turk J Bot 22:73-91

Post G (1932) Flora of Syria, Palestine and Sinai, vol I. American Press, Beirut, pp 427-434

Punt W, Blackmore S, Nilsson Le Thomas A (1994) Glossary of pollen and spores terminology. Lab Paleobot Palynol, Utrecht

Rechinger KH (1979) Lathyrus L In: Chrtkova-Zertova A, van der Maesen LJG, Rechinger KH (eds) Flora Iranica, no. 140, Papillionaceae, vol I. Vicieae. Akademische Druck und Verlagsanstalt, Graz

Tosheva A, Tonkov S (2005) Pollen morphology of Bulgarian species from the section Orobus (L.) Gren. Et Godr. (genus Lathyrus, Fabaceae). Acta Bot Croat 64:275-287

Tosheva A, Tonkov S (2007) Pollen morphology of the Bulgarian species from section Lathyrostylis (genus Lathyrus, Fabaceae). Phytol Balcanica 13(3):393-400

Tosheva A, Tonkov S, Dimitrov N (2004) Pollen morphology of Bulgarian species from the section Lathyrus (Lathyrus, Fabaceae). Phytol Balcanica 9:529-536

Townsend CC, Guest E (1977) Flora of Iraq. Ministry of agriculture and agrarian reform of the republic of Iraq, Baghdad, pp 549-573

Tutin TG, Heywood VH (1981) Lathyrus L Flora Europaea, vol 2. Cambridge University Press, Cambridge, pp 136-145

Whyte RO, Nilson-Leissner G, Trumble HC (1953) Legumes in agriculture. FAO, Rome

Wodehouse RP (1959) Pollen grains, their structure, identification and significance in science and medicine. Hafner, New York

Yamamoto K, Fujiwara T (1984) Karyotypes and morphological characteristics of some species in the genus Lathyrus L. Japan J Breed 34:273-284

Zohary M (1987) Flora Palaestina, The Israel academy of sciences and humanities Jerusalem. Part two, 211-221 